【論 文】

UDC : $534.831: 628.517: 696 / 697$

\title{
グラス・ファイバ・ダクト直管部，曲管部および 分岐部の気流および音響特性について
}

\section{1. 緒 言}

グラス・ファイバ・ダクトは，米国で開発され，約 25 年前から我が国でも用いられるようになった。最近 では年間数百件以上の各種用途の建築に用いられてお り,当初の博覧会用パビリオンのみでなく,コンサート・ ホールなジ大規模な建築にも広く採用されている。

グラス・ファイバ・ダクトは，従来の鉄板ダクトに比 較して, 消音, 断熱, 気密, 軽量なざ多くの特質を有す る。しかしながら，ダクト側壁が軽量のグラス・ファイ バで構成されているため，ダクト内の音響減衰は大きい が，ダクト壁の遮音量が小さく，ダクト内から外へ，ま た，ダクト外から内へと容易に音が透過する。

こうした特質に着目した研究も，勝田ほが ${ }^{1)}$, 長友ほ が2にによって行われてきたが，われわれは，グラス・ファ イバ・ダクト系すべてのエレメントについて，それらの 気流および音響特性を明らかにし，グラス・ファイバ・ ダクト系の設計が合理的に行えるための基礎資料を得る こととした ${ }^{31-99}$ 。

本報告では，前述の目的の一部として，グラス・ファ イバ・ダクトの直管部,曲管部および分岐部を取り上げ, それらの損失圧力, 音響減衰わよび直管側壁の遮音特性 を明らかにする。

\section{2. 供試体の種類}

供試体を図一1に示す。供試体は円形断面直管部 3 種 (Type A), 正方形および長方形断面直管部 8 種 (Type B), 円形断面曲管部 15 種 (Type C), 正方形および長 方形断面曲管部:23 種 (Type D), 円形断面分岐部 6 種 (Type E), 正方形および長方形断面分岐部 17 種 (Type F) である。なお，円形断面直管部 $200 \Phi$ おび $300 \Phi$ はグラス・ヤーン有無の音響特性を検討するために 2 種 類ある。また，曲管部および分岐部は，ガイドベーン付 きがあり (Type D-3, F-4 およびF-9)，特に，Type D-3では，グラスウール製ガイドベーンが 1 種，アル

本論文は日本建築学会, 空気調和・衛生工学会および空気調和・冷凍連 合講演会において発表した文献 3）および5)－9）の内容を再検討し，ま とめ直したものである。

*日本大学 教授・工博

** 日本大学 助手.工修 (昭和 63 年 6 月 10 日原稿受理)

$\begin{array}{lllll}\text { 正会員 } & \text { 板 } & \text { 本 } & \text { 守 } & \text { 正* } \\ \text { 正会員 } & \text { 塩 } & \text { 川 } & \text { 博 } & \text { 義** }\end{array}$

ミニウム製ガイドベーンが 2 種あり，後者はベーンの数 が少なく長さが長いものを $L$ ，数が多く長さが短いも のを $S$ として区別する。分岐部は，すべてアルミニウ ム製ガイドベーンである。

ダクトの側壁を構成するグラス・ファイバは, 厚さ $25 \mathrm{~mm}$, 密度 $60 \mathrm{~kg} / \mathrm{m}^{3}$ で, 外面は $0.08 \mathrm{~mm}$ 厚のアルミ 箔を貼りつけ，ダクトの内表面は，円形断面では消石灰 とボンドとを混合したものを吹き付け，正方形および長 方形断面ではグラス・ファイバの表面を焼き付け処理し てある。グラスウール製ガイドベーンの密度および表面

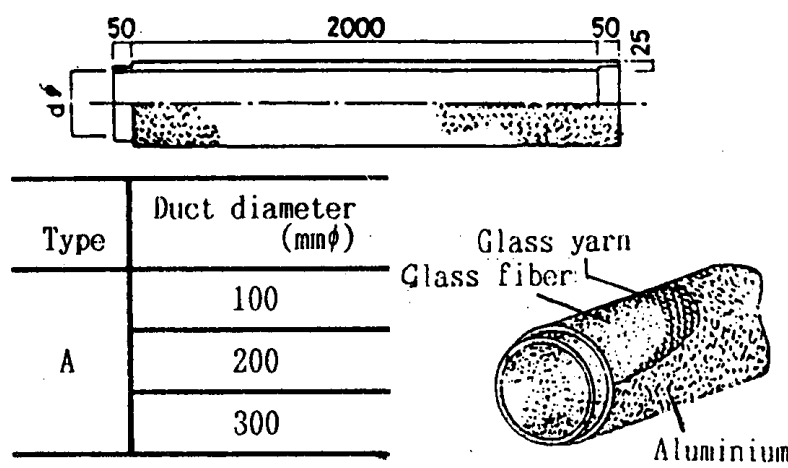

foil

Type A : Round section ducts
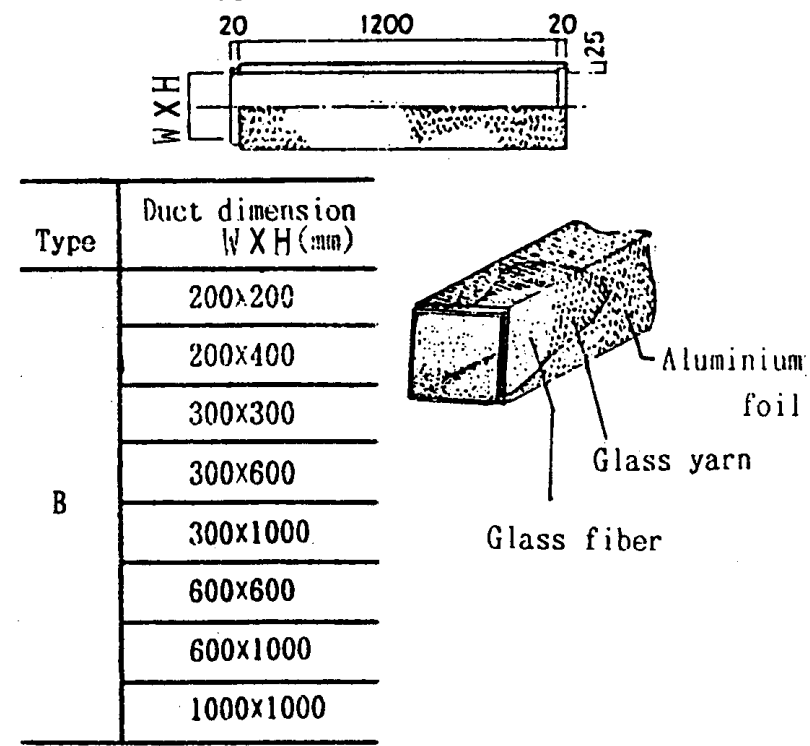

Type B : Rectangular section ducts 図一1 供試体の種類（次頁につづく） 

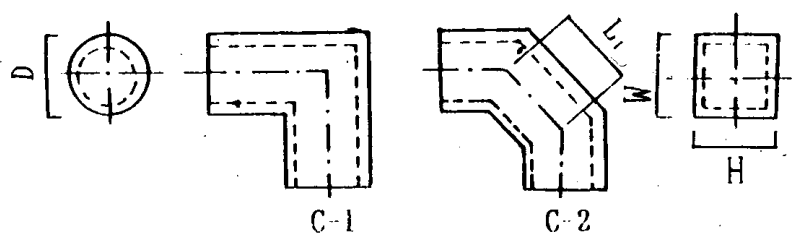

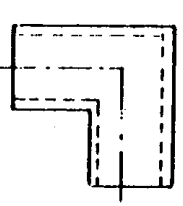

() -1

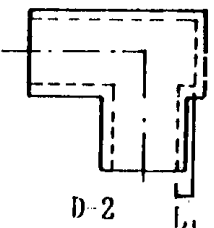

2
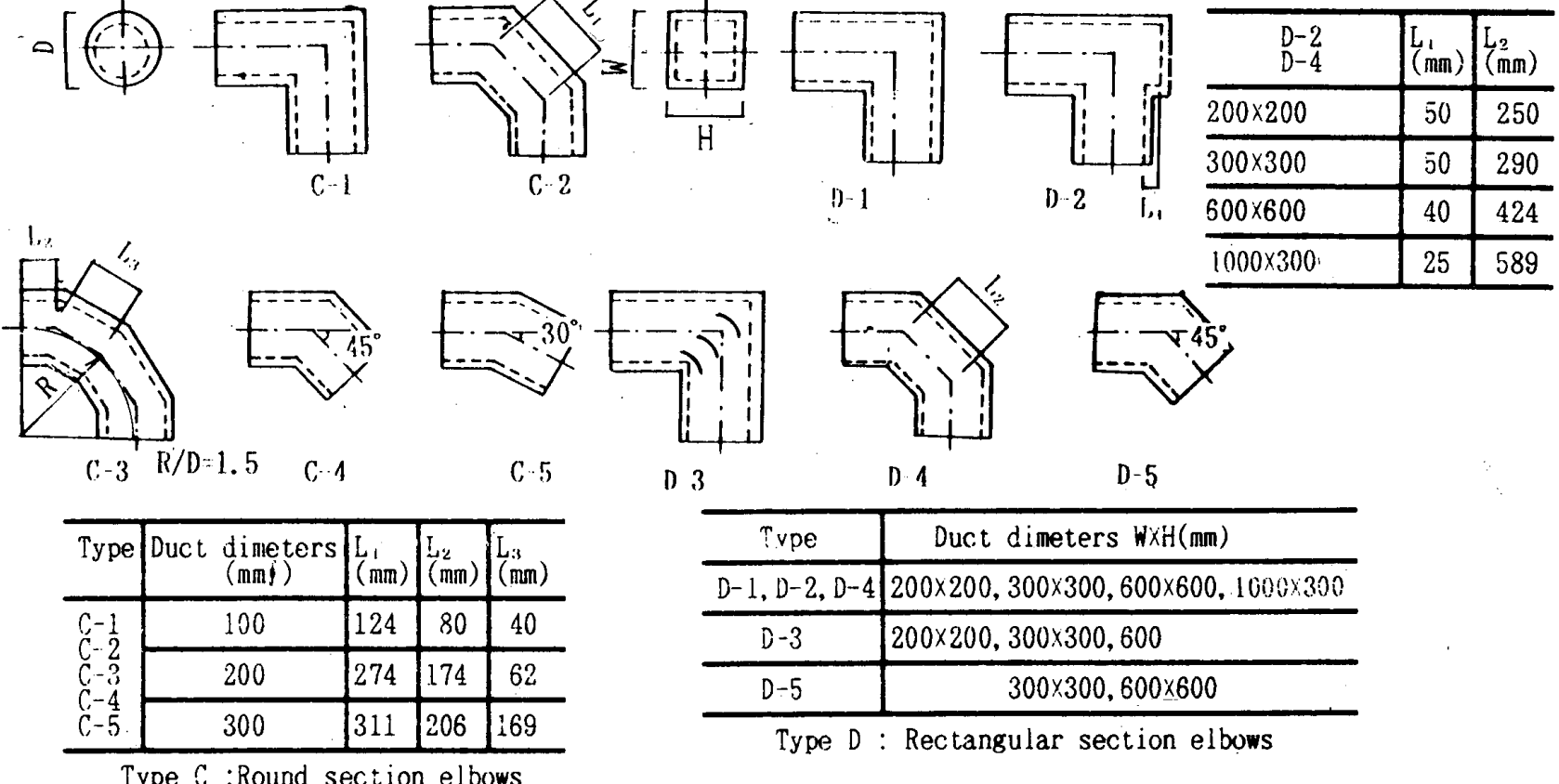

5

D 3

D. 1

D-5

\begin{tabular}{c|c}
\hline Tvpe & Duct dimeters WXH(mm) \\
\hline$D-1, D-2, D-4$ & $200 \times 200,300 \times 300,600 \times 600,1000 \times 300$ \\
\hline$D-3$ & $200 \times 200,300 \times 300,600$ \\
\hline$D-5$ & $300 \times 300,600 \times 600$ \\
\hline
\end{tabular}

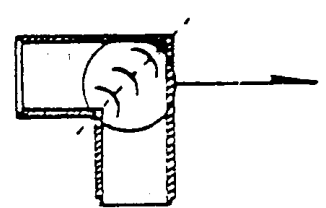

Air Flow

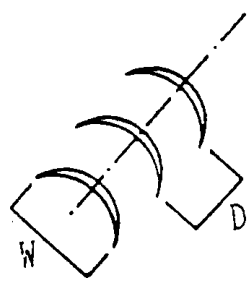

\begin{tabular}{c|c|c|c|c|c}
\hline \multicolumn{3}{c|}{ Duct diameters $(\mathrm{mm} j)$} \\
\hline \multicolumn{3}{c|}{$\mathrm{E}-1$} & \multicolumn{3}{c}{$\mathrm{E}-2$} \\
\hline 0 & 1 & 2 & 0 & 1 & 2 \\
\hline 200 & 200 & 150 & 200 & 150 & 150 \\
\hline 250 & 250 & 200 & 250 & 200 & 200 \\
\hline 300 & 300 & 250 & 300 & 250 & 200 \\
\hline
\end{tabular}

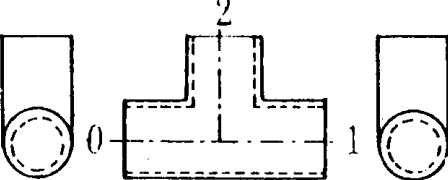

E. 1

Typ- E : Round section divided-flu fitting
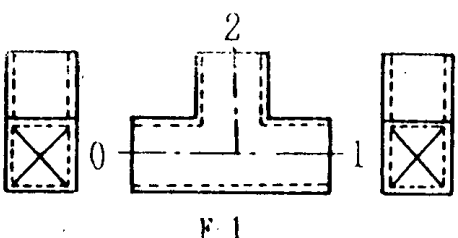

2
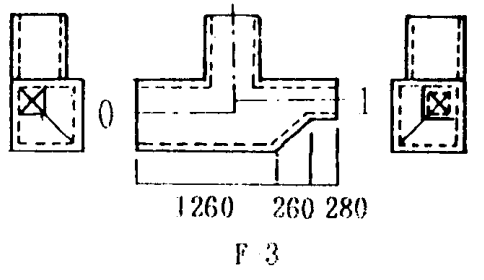

\begin{tabular}{|c|c|c|c|c|c|}
\hline $\begin{array}{c}\text { Duct dimensions } \\
\mathrm{mm}\end{array}$ & - Materia & & $\begin{array}{l}\text { Number of } \\
\text { guide vanes }\end{array}$ & $\begin{array}{l}W \\
\mathrm{~mm}\end{array}$ & $\begin{array}{l}\mathrm{D} \\
\mathrm{mm}\end{array}$ \\
\hline \multirow{3}{*}{$200 \times 200$} & \multicolumn{2}{|l|}{ Glass wool } & 3 & 170 & 70 \\
\hline & \multirow{2}{*}{ Aruminium } & L & 2 & 135 & 100 \\
\hline & & $S$ & 3 & 75 & 70 \\
\hline \multirow{3}{*}{$300 \times 300$} & \multicolumn{2}{|c|}{ Glass wọol } & 4 & 170 & 90 \\
\hline & \multirow{2}{*}{ Aruminium } & L & 3 & 135 & 100 \\
\hline & & $S$ & 5 & 75 & 70 \\
\hline \multirow{3}{*}{$600 \times 600$} & \multicolumn{2}{|c|}{ Glass wool } & 3 & 170 & 90 \\
\hline & \multirow{2}{*}{ Aruminium } & L & 6 & 135 & 125 \\
\hline & & $S$ & 9 & 75 & 90 \\
\hline
\end{tabular}

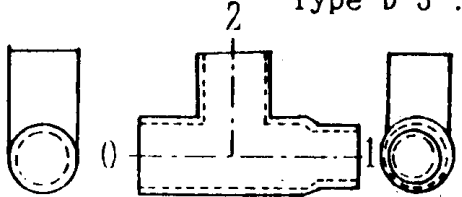

F. 2
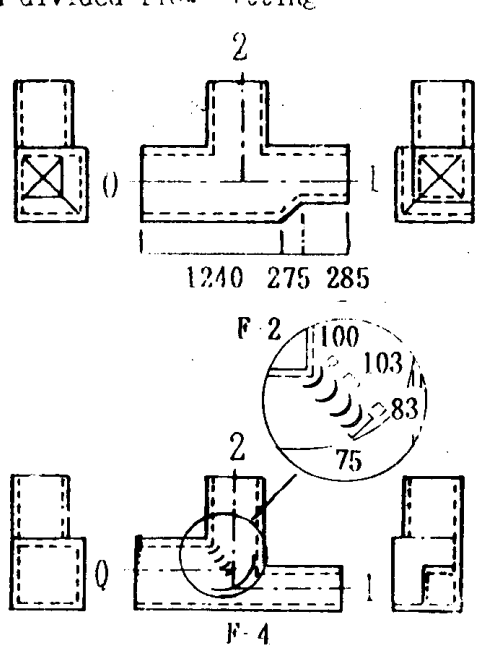
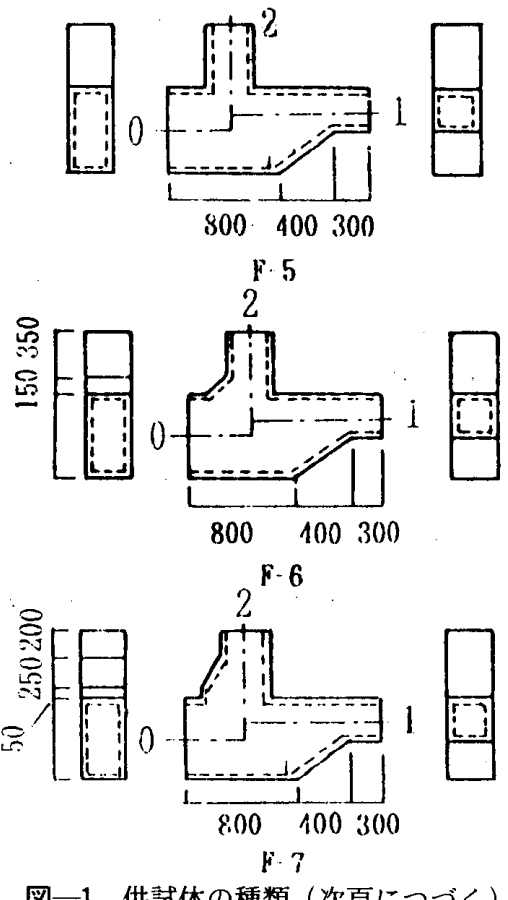


\begin{tabular}{|c|c|c|c|c|c|c|c|}
\hline \multicolumn{8}{|c|}{ Duct dimensions $W \times H(m)$} \\
\hline Type & 0 & 1 & 2 & Type & 0 & 1 & 2 \\
\hline \multirow{4}{*}{$E-1$} & $200 \times 200$ & $200 \times 200$ & $200 \times 200$ & \multirow{2}{*}{$F-6$} & $600 \times 600$ & $300 \times 300$ & $300 \times 300$ \\
\hline & $300 \times 300$ & $300 \times 300$ & $300 \times 300$ & & $1000 \times 300$ & $700 \times 300$ & $300 \times 300$ \\
\hline & $600 \times 600$ & $600 \times 600$ & $600 \times 600$ & \multirow{2}{*}{$F-7$} & $600 \times 300$ & $300 \times 300$ & $300 \times 300$ \\
\hline & $300 \times 1000$ & $300 \times 1000$ & $300 \times 1000$ & & $1000 \times 300$ & $700 \times 300$ & $300 \times 300$ \\
\hline F-2 & $600 \times 600$ & $450 \times 450$ & $450 \times 450$ & \multirow{2}{*}{ F-8 } & $600 \times 300$ & $300 \times 300$ & $300 \times 300$ \\
\hline $5-3$ & $600 \times 600$ & $250 \times 250$ & $450 \times 450$ & & $1000 \times 300$ & $700 \times 300$ & $300 \times 300$ \\
\hline$F-4$ & $600 \times 600$ & $250 \times 250$ & $450 \times 450$ & \multirow{2}{*}{ F-9 } & $600 \times 300$ & $300 \times 300$ & $300 \times 300$ \\
\hline \multirow{2}{*}{$F-5$} & $600 \times 300$ & $300 \times 300$ & $300 \times 300$ & & $1000 \times 300$ & $700 \times 300$ & $300 \times 300$ \\
\hline & $1000 \times 300$ & $700 \times 300$ & $300 \times 300$ & & & & \\
\hline
\end{tabular}

Type F : Rectangular section divided-flow fittings
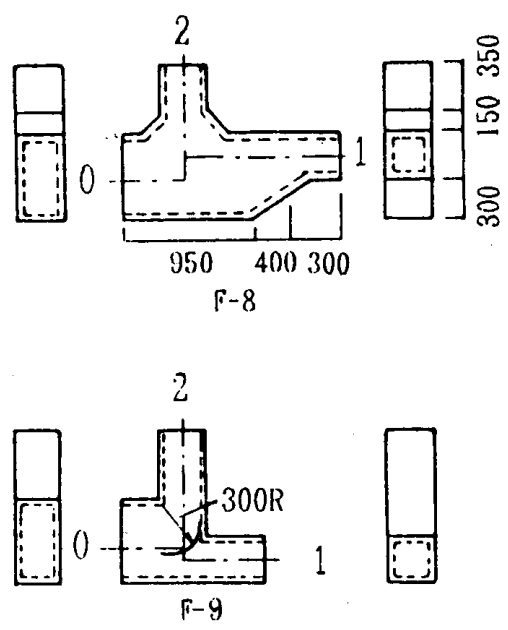

图一1 供試体の種類
処理も上記と同様である。

また，各実験時におけるグラス・ファイバ・ダクトや 鉄板ダクトの取り付け方法は, 現場での施工方法と同様 に行っている。

\section{3. 実験装置および方法}

3-1: 損失圧力

実験装置を図一 2 に示す。ダクト系に送風し, 供試体 上下流側鉄板ダクト側壁に設置した静圧管によりダクト 軸方向静圧分布を 4 段階以上の流速について測定する。 静圧は, ダクト断面で上下左右 4 点, ダクト軸方向に 24 点 (Type F-1 4 は 36 点), 合計 96 点 (Type F-1 ４ は 144 点）で测定をする。直管部はグラス・ファイ バ・ダクト入口および出口の全圧差から単位長さ $(1 \mathrm{~m})$
当たりの圧力差（式 $(1)$ ) を求めて, これを損失圧力 とする。また, 損失圧力より供試体入口の平均流速の速 度圧と等価直径とを考慮して摩擦抵抗係数入（式（2）） を求め, 4 流速以上の $\lambda$ の平均をその直管部の摩擦抵 抗係数入とする。

曲管部および分岥部はグラス・ファイバ・ダクト入口 および出口における全圧差からグラス・ファイバ・ダク 卜直管部の損失圧力を考慮して上下流側ダクト中心軸交 点での全圧差（式 (3) および式 (4)) を求め, これ らを損失圧力とする。また, 損失圧力を供試体入口の平 均流速の速度王で除して形状抵抗係数 $($ (式 $(5))$ を 求め, 4 流速以上の の形状抵抗係数

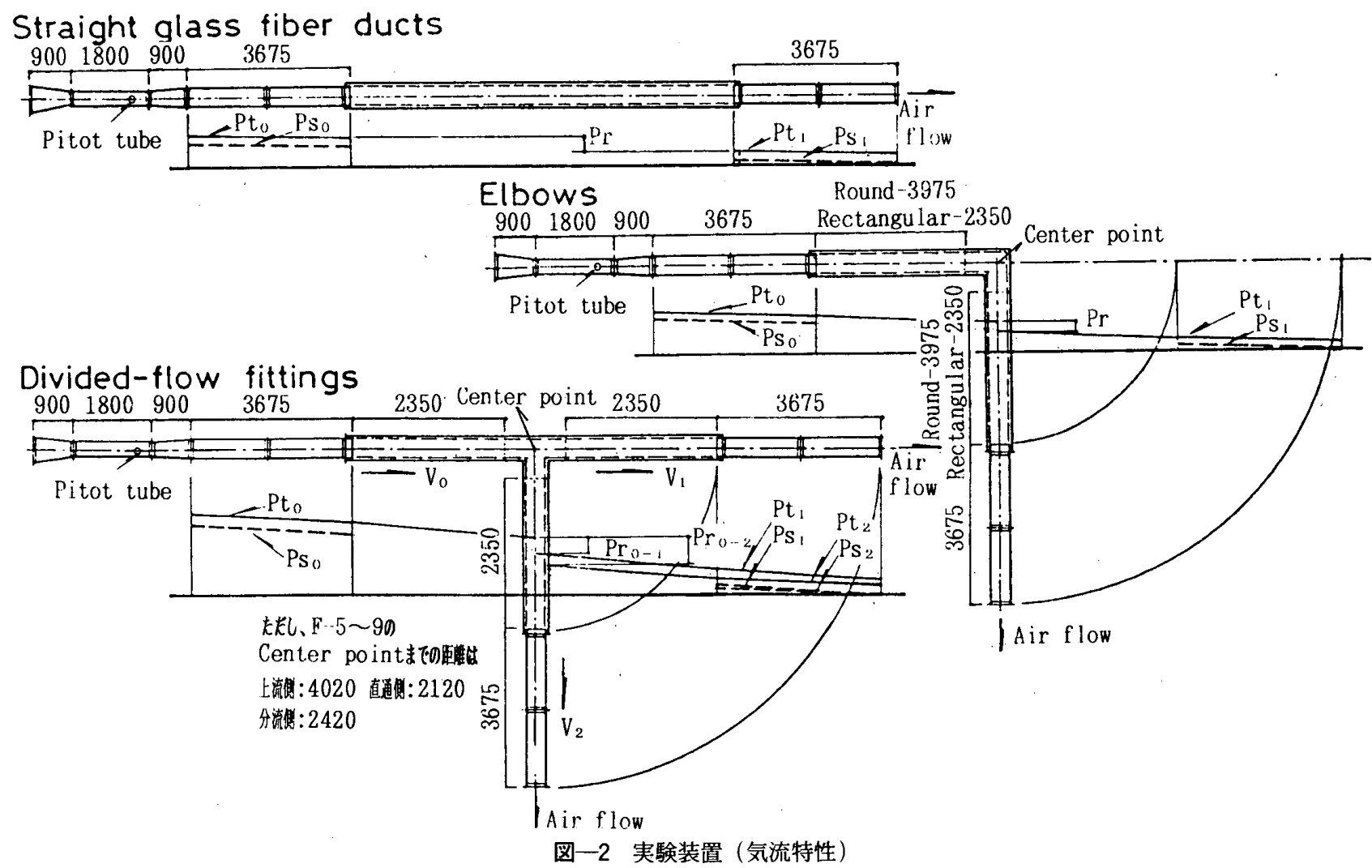


供試体入口の平均流速は，各ダクトの上流にある流量 測定用ダクトのピト一管により求める。

分岐部は, 供試体上流側ダク卜の流量 $\left(Q_{0}\right)$ と分岐 直通ダクトの流量 $\left(Q_{1}\right)$ との比 $Q_{1} / Q_{0}$ を $1 \sim 0$ の間で変 化させた場合について実験を行う。また，この場合は直 通あるいは分流側のいずれか一方の鉄板ダクト出口にダ ンパを取り付け，他方の出口においてピト一管により平 均流速を測定し，流量を調整する。

$$
\begin{aligned}
& P r_{0-1}=\frac{P t_{0}-P t_{1}}{l} \\
& \operatorname{Pr}=\lambda \cdot \frac{l}{D} \cdot \frac{\gamma}{2 g} \cdot V^{2} \\
& P r_{0-1}=\left(P t_{0}-\lambda_{0} \cdot \frac{l_{0}}{D_{0}} \cdot \frac{\gamma}{2 g} \cdot V_{0}^{2}\right) \\
& -\left(P t_{1}+\lambda_{1} \cdot \frac{l_{1}}{D_{1}} \cdot \frac{\gamma}{2 g} \cdot V_{1}^{2}\right) \\
& P r_{0-2}=\left(P t_{0}-\lambda_{0} \cdot \frac{l_{0}}{D_{0}} \cdot \frac{\gamma}{2 g} \cdot V_{0}^{2}\right) \\
& -\left(P t_{2}+\lambda_{2} \cdot \frac{l_{2}}{D_{2}} \cdot \frac{\gamma}{2 g} \cdot V_{2}^{2}\right) \\
& \operatorname{Pr}=\zeta \cdot \frac{\gamma}{2 \mathbf{g}} \cdot V^{2}
\end{aligned}
$$

ただし，

$$
P t=P s+\frac{\gamma}{2 g} \cdot V^{2}
$$

$P r$ : 損失圧力 $\left[\mathrm{kg} / \mathrm{m}^{2}\right](0:$ 上流側, $1:$ 下流側 '(分 岐部の場合直通側)，2：分岐分流側）

$P t:$ 全圧 $\left[\mathrm{kg} / \mathrm{m}^{2}\right]$

$P s:$ 静圧 $\left[\mathrm{kg} / \mathrm{m}^{2}\right]$

$l:$ 管長 $[\mathrm{m}]$

$D$ ：直径 $[\mathrm{m}] （ D$ は，管が円形断面でない場合には 次式による等価直径を用いる。 $D=4 \times$ 断面積/ 周長)

$V:$ 供試体入口あるいはダクト内の平均流速 $[\mathrm{m} / \mathrm{s}]$

$\gamma:$ 空気比重量 $\left[\mathrm{kg} / \mathrm{m}^{3}\right]$

$\lambda:$ 摩擦抵抗係数

$\zeta:$ 形状抵抗係数

\section{3-2：音響減衰}

グラス・ファイバ・ダクトの音響的特質である音響減 衰を求める方法は，まだ確立されていないため，ダクト 内の音圧分布測定値の傾向から，実務的見地に立って音 響減衰を求める方法を以下に述べる。

実験装置を図一3に示す。スピーカより 1/1オクター ブ・バンド・ノイズを発生し, 供試体前後のダクト内中 心軸方向音圧レベル分布を測定する。

出発点あるいは中心点からの距離を横軸に, 測定結果 の音圧レベルを縦軸にして表したものを図一4〜6に示 す。ダクト内中心軸に示す点が音圧レベルの測定点を示 し，曲管部および分岐部の下流側はすべて音圧レベルを 上流側中心軸の延長上にもってきて表している。
図一 4 の直管部の例によれば, 出発点の最初の $1 \mathrm{~m}$ で は多少乱れて急な減衰に, $1.2 \sim 3 \mathrm{~m}$ では距離に比例し て直線的に减衰しており，3 $\mathrm{m}$ 以降は少しなだらかに なっている。最初の $1 \mathrm{~m}$ では鉄板ダクト直後であるた め, 多少音響的な影響が見られ，3 $\mathrm{m}$ 以降では暗騒音に 近づくためと考えられるので,グラス・ファイバ・ダク 卜直管部そのものの音響減衰量は, この場合, $1.2 \sim 3$ $\mathrm{m}$ 間の值から求めるこどが妥当と考えられる。1.2 3 $\mathrm{m}$ 間の音圧レベルによれば, 前述のように, グラス。 ブアイバダクト直管部の音響減衰は，ほぼ距離に対し て直線的に減衰する。ごれは，他の直管部供試体のいず
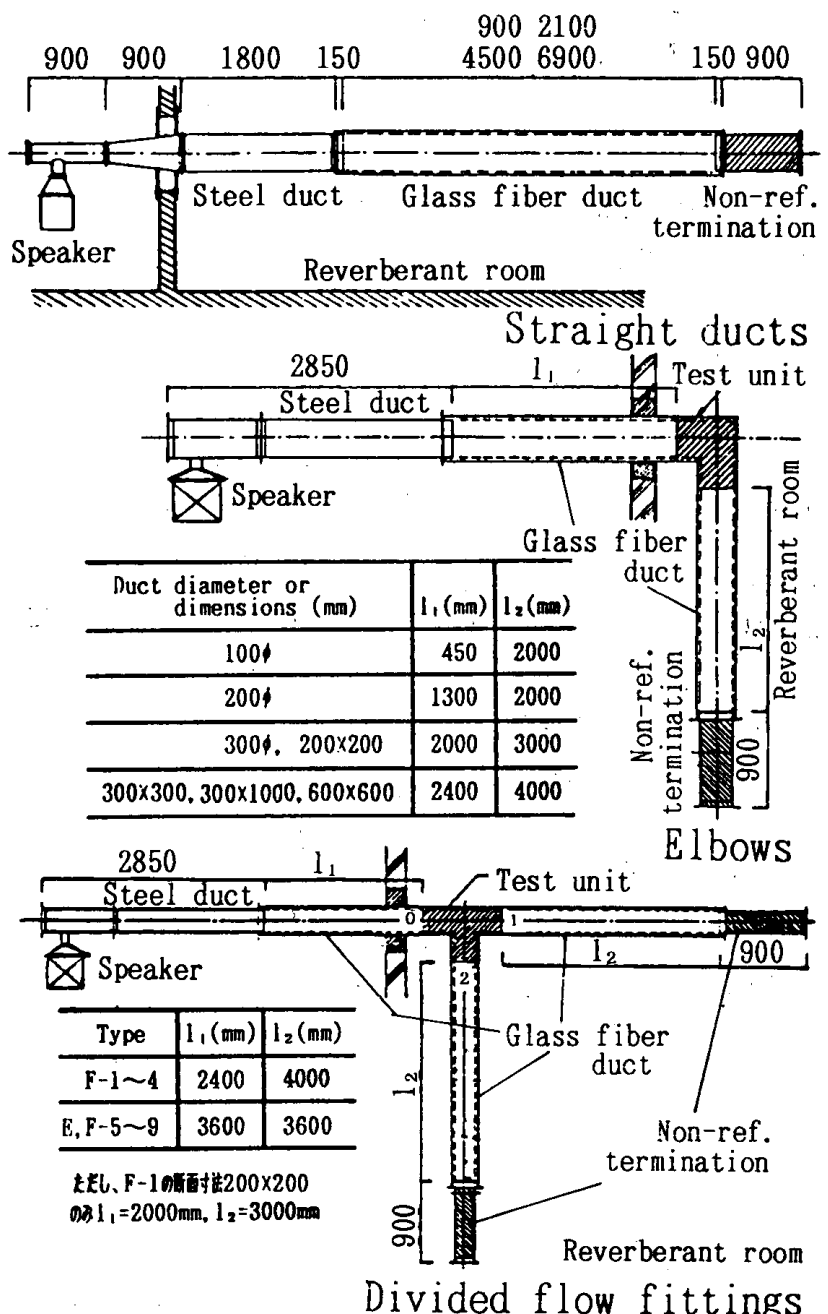

图一3 実験装置（音響減衰）

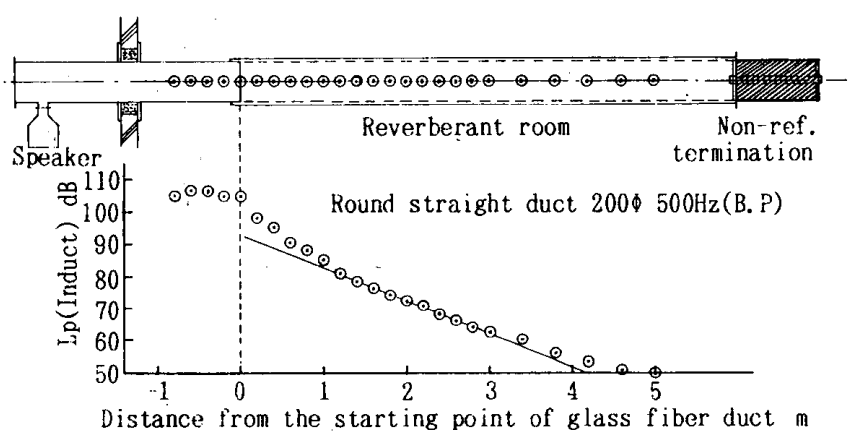

図一4 直管部の音響減衰 
れの周波数帯域においてもほぼ同様な傾向を示してお り,このことから, その直線の傾きを求めて $1 \mathrm{~m}$ 当た りの減衰量を直管部の音響娍衰とする。

ただし，この音響減衰は，グラス・ファイバ・ダクト と鉄板ダクトとを接続する場合, 設計上, 単純に用いる ことはできない。グラス・ファイバ・ダクトと鉄板ダク トとを併用して用いる場合，図一4に示したように鉄板 ダクト直後 $1 \mathrm{~m}$ くらいまでとそれ以後とでは音響特性 に違いが見られる。そこで，上で示した音響減衰と同様 に鉄板ダクト直後 $1 \mathrm{~m}$ までの減衰量もダクト設計上必 要と考えるので上記の音響減衰とともに示すことにす

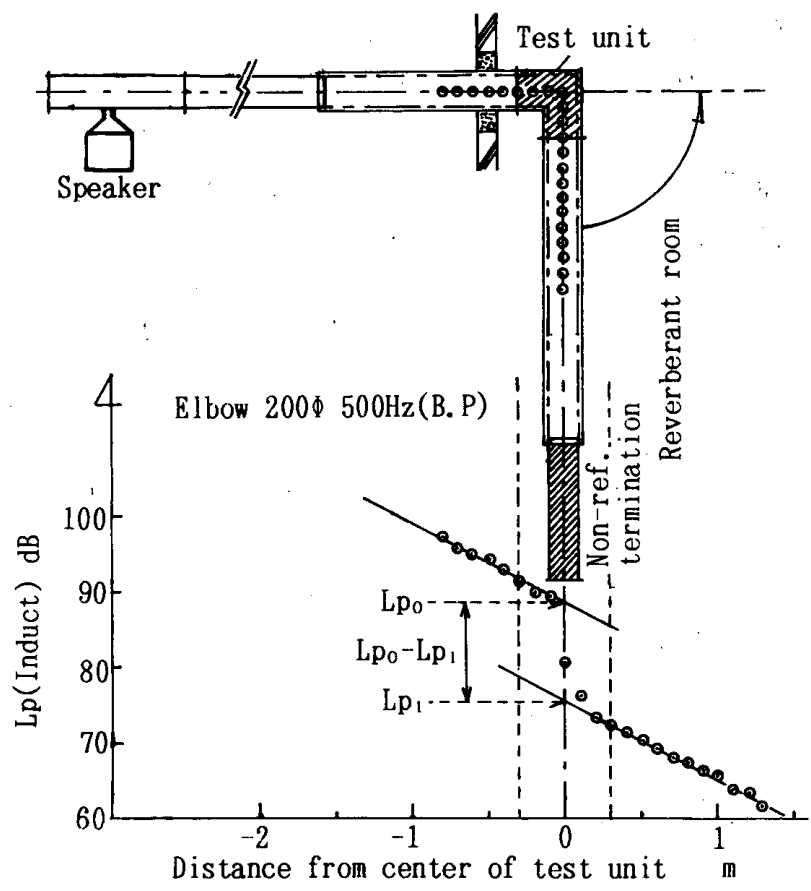

図一5 曲管部の音響減衰

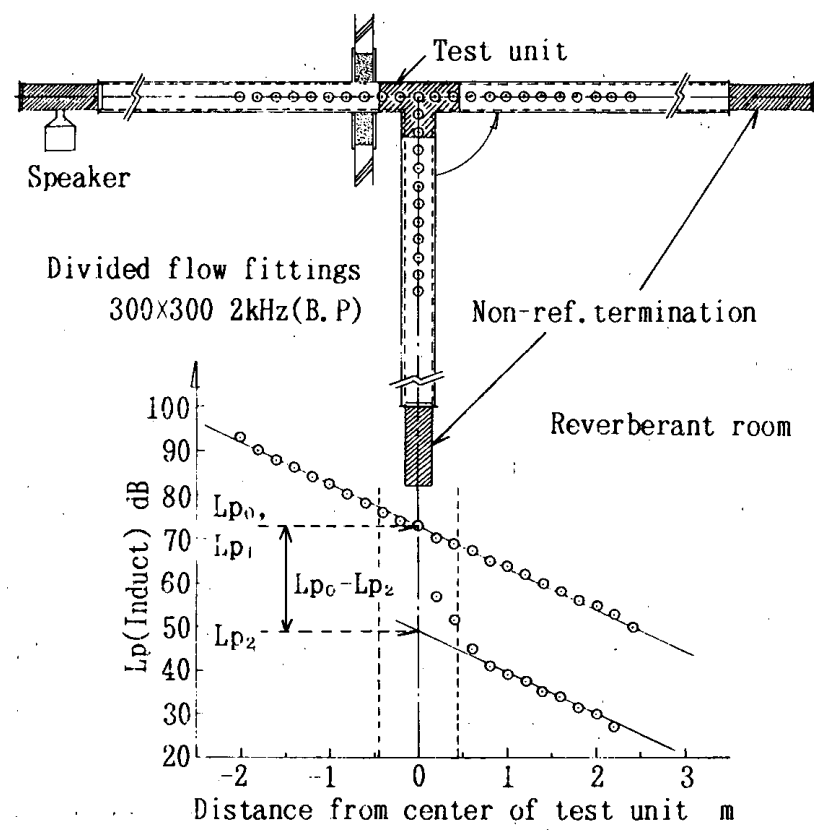

图一6 分岐部の音響減衰
る。

図一5 および図一6の曲管部および分岐部の例によれ ば上下流側ダクトいずれも直管部で求めた音響減衰量の 直線の傾きにほぼ乗っている。これは，他の曲管部およ び分岐部供試体のいずれの周波数帯域においてもほぼ同 様な傾向を示しており，このことから，上下流側それぞ れの音圧レベルに直管部で求めた傾きの直線を乗るよう に引き，その直線を中心点まで延ばしてその交点の音圧 レベルをそれぞれ求め, 上下流側ダクト断面寸法が等し い場合はその音圧レベル差を，異なる場合はそれぞれの ダクト断面積を考慮したパワーレベル差を求めて曲管部 および分岐部の音響減衰とする。(式（6）および（７）） ただし，一般的に，管内において平面進行波でなければ 音圧レベルと音の強さのレベルとをほぼ等しいと考える ことはできないが，あくまで実務的な見地から中高音域 を含めてダクト内はすべて平面進行波と考えて計算して いる。

$$
\begin{aligned}
& L w_{0-1}=L p_{0}-L p_{1}+10 \log _{10}\left(\frac{S_{0}}{S_{1}}\right) \\
& L w_{0-2}=L p_{0}-L p_{2}+10 \log _{10}\left(\frac{S_{0}}{S_{2}}\right)
\end{aligned}
$$

ただし，

$L w$ ：音響减衰量 $[\mathrm{dB}](0$ ：上流側，1：下流側（分 岐部の場合直通側)，2：分岐分流側）

$L p:$ ダクト内音圧レベル $[\mathrm{dB}]$

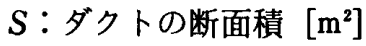

3-3：ダクト側壁の遮音特性

遮音特性も音響減衰同様グラス・ファイバ・ダクトの 音響的特質のひとつであるが, 単に,グラス・ファイバ・ ボード $25 \mathrm{~mm}$ 厚の透過損失を求めてもダクト設計上簡 単には使用できない。そこで，実務的に，ダクト設計で 鉄板ダクトとグラス・ファイバ・ダクトとを併用する場 合の遮音特性を示す。

エネルギー的に考えれば(図一7),グラス・ファイバ・ ダクトに比して側壁の透過がほとんビない鉄板ダクトか ら $W_{1}$ の音響エネルギーを持つ音波がグラス・ファイ バ・ダクトに入射するときに，鉄板ダクトとグラス・ ファイバ・ダクト内との音響インピーダンスが異なるた め $W_{1}$ のエネルギーの一部は $W_{1 R}$ として反射し，また， 一部はダクト自体に吸収されて残りのエネルギーが入射 する。入射したエネルギーは，ダクト内を進行するが，

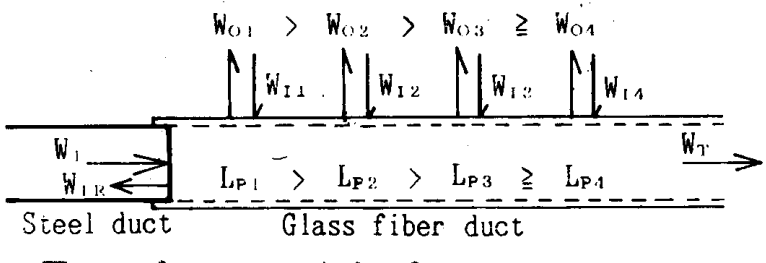

図一7 グラス・ファイバ・ダクト通過時のエネルギー 


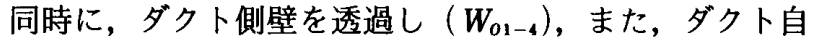
体に吸収される。さらに,ダクト外にある音響エネルギー や，すでにダクト外に透過したエネルギー $\left(W_{11-4}\right)$ が またダクト内に入ってくる。この関係が繰り返されて鉄 板ダクトから離れるに従ってダクト内音圧レベル $(L p)$ は減衰し, ある程度離れると減衰しなくなりダクト外に 透過していく $W_{0}$ もあまり変化しなくなる。

今回は，ダクト設計資料として鉄板ダクトからグラ ス・ファイバ・ダクトに入射してくるエネルギー $\left(W_{1}\right)$ とダクト側壁から放射されるエネルギー $\left(W_{o 1-4}\right)$ との 差をパワーレベル差で表し，それらをダクト内から外へ 透過する場合の遮音特性とし，ダクト外から側壁へ入射 してくるエネルギー $\left(W_{I}\right)$ 亡，それらがダクト内へ入 射してグラス・ファイバ・ダクト内を通過する音に影響 をあたえるエネルギーとの差をパワーレベル差で表し， それらをダクト外から内へ入射する場合の遮音特性とし て 2 種類の実験を行った。

ダクト内から外へ透過する場合, ダクト内の音響減衰 之同様に図一8(a) のダクト系を用いて行う。まず，3-2 で求めたダクト内音圧レベル分布から鉄板ダクト出口の パワーレベル $\left(L w_{1}\right)$ を求める。次に, 図一8(a) のダ クト系からの透過音による残響室内平均音王レベル $\left(L p_{o}\right)$ を測定し, 透過音のパワーレベル $\left(L w_{R 1}\right)$ を 求める(式 $(8))$ 。さらに, 図一8(b) のダクト系につ いて同様に透過音のパワーレベル $\left(L w_{R 2}\right)$ を求める。 供試ダクト側壁からの透過パワーレベル $\left(L w_{0}\right)$ は, $L w_{R 1}$ から $L w_{R 2}$ をエネルギ一的に減じて求める（式 (9))。なお, 図一8(a) および (b) におけるスピー 力音響出力の変化は測定值に影響のないことを確かめて
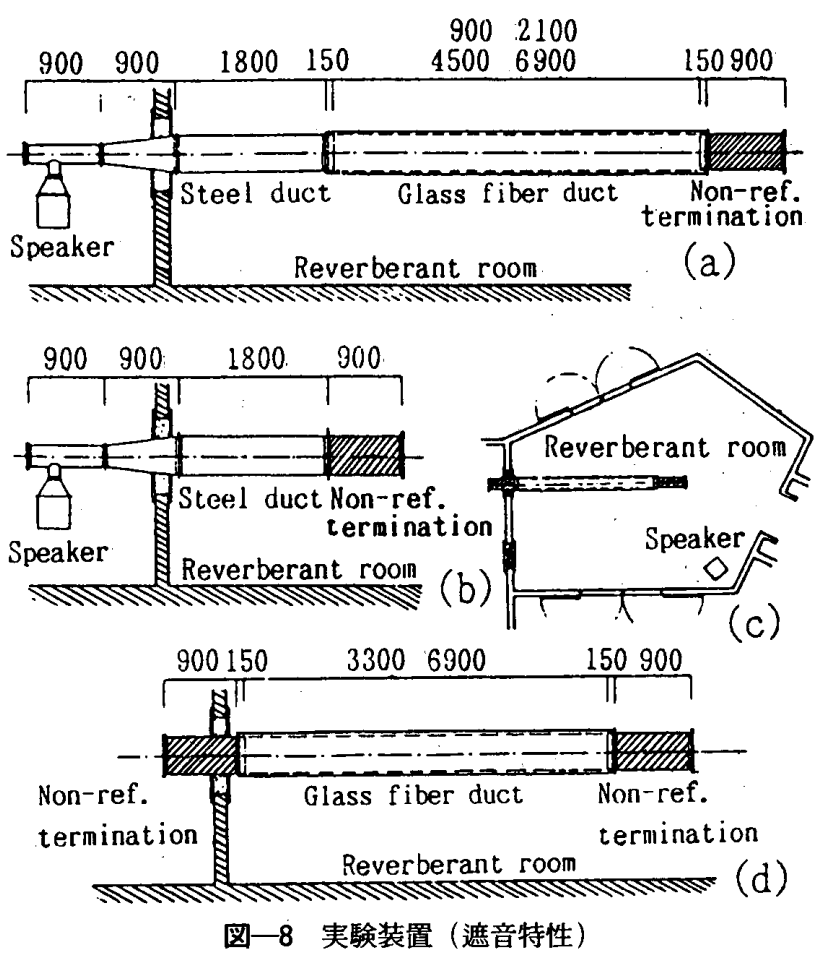

ある。

供試ダクトの長さを $0.9 ， 2.1 ， 4.5$ および $6.9 \mathrm{~m} に$ 変化させたときの $L w_{1}$ と $L w_{o}$ との差はいずれもほとん ど変化しない（図一9参照）。これは，供武体へ入射し た音がほとんど入射直後のほぼ $1 \mathrm{~m}$ 以内でダクト側壁 から透過するためと考えられる。したがって，ダクト側 壁からの透過音は, 鉄板ダクト出口から約 $1 \mathrm{~m}$ のダク 卜側壁の透過エネルギーが主なものと考え，ダクト内か ら外へ透過する場合の遮音特性は, 鉄板ダクトからの入 射音のパワーレベルとその鉄板ダクトと接続されてから $1 \mathrm{~m}$ 以内の側壁からの透過パワーレベルとの差として 表すこととする（式 $(10))$ 。ただし，ここでの遮音特性 は, 前述したように, グラス・ファイバ・ダクト側壁そ のものの遮音量ではなく, ダクト系の設計において, 鉄 板ダクト内からグラス・ファイバ・ダクトに入射する軸 方向進行音がよ゙れだけダクト外部へ透過するか求めるこ とを考えての遮音特性である。

$$
L w_{R 1 \text { or } 22}=L p_{01 \text { or } 02}+10 \log _{10}\left(\frac{55.3}{C} \cdot \frac{V_{0}}{T_{1 \text { or } 2}}\right)-6
$$

$L w_{0}=10 \log _{10}\left(10^{L w R 1 / 10}-10^{L w R 2 / 10}\right)$

Difference of $L w=L w_{1}-L w_{0}$

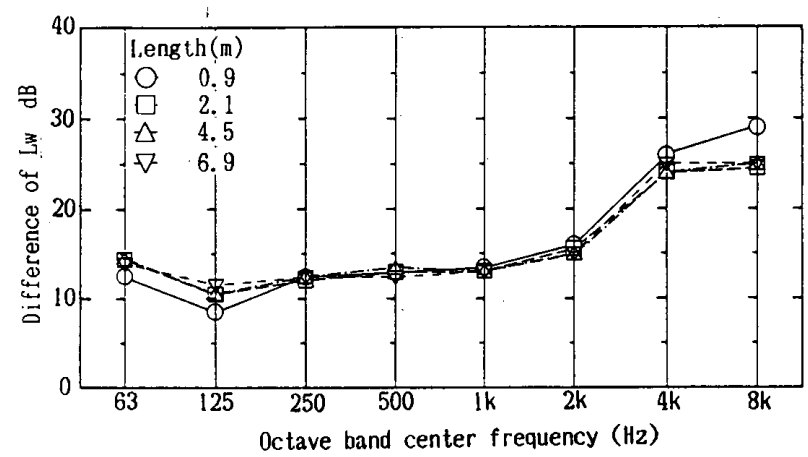

図一9 供試ダクトの長さによるダクト内から外へ透過する場合 の遮音特性

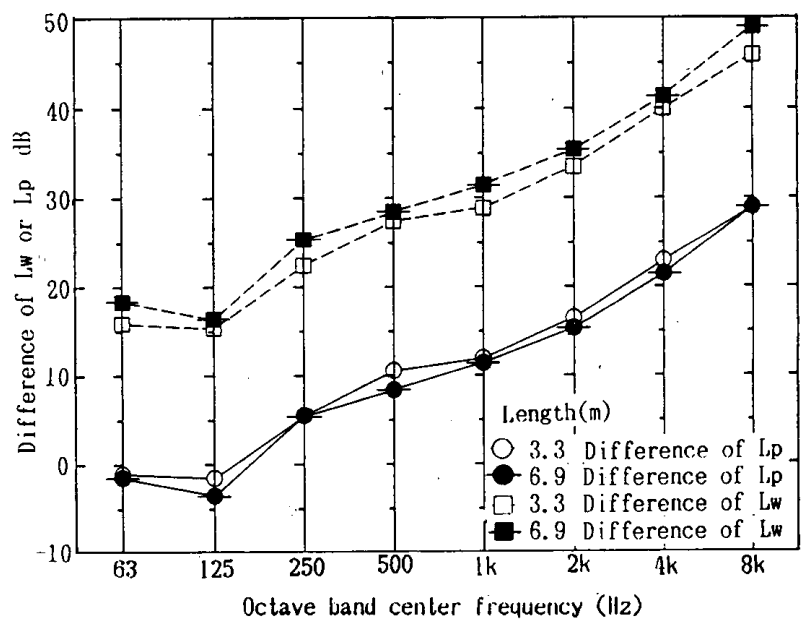

図一10 供試ダクトの長さによるダクト外から内へ透過する場 合の遮音特性 
$L w_{1}$ : 供試体入口のパワーレベル $[\mathrm{dB}]$

$L w_{0}$ ：供武ダクト側壁の透過パワーレベル $[\mathrm{dB}]$

$L p_{0}$ : 残響室内平均音圧レベル

$L w_{R 1}$ : 図一8 $(\mathrm{a})$ で求めた透過パワーレベル $[\mathrm{dB}]$

$L w_{R 2}$ : 図一8(b) で求めた透過パワーレベル $[\mathrm{dB}]$

$C:$ 音速 $[\mathrm{m} / \mathrm{s}]$

$V_{0}:$ 室容積 $\left[\mathrm{m}^{3}\right]$

$T:$ 残響時間 $[\mathrm{s}]$

ダクト外から内へ入射する場合は, 図一8(c) および （d）に示すダクト系で行う。まず，残響室内に設置し たスピーカより $1 / 1$ オクターブ・バンド・ノイズを発生 し, 残響室内平均音圧レベル $\left(L p_{o}\right)$ を測定し, ダクト 表面積を考慮した式（11）よりダクト側壁へ入射するパ ワーレベル $\left(L w_{1}\right)$ を求める。式 $(11)$ では, 実際に, ダクトが設置される場所は，拡散音場とは言いがたい所 が多いため，あえてダクト外側の室内音圧レベル $L p_{o}$ にダクト表面を考慮したものを入射パワーレベルとし た。

つぎに，供試ダクト内中心軸方向音圧レベルを 20 ポ イント以上測定する。いずれのポイントも音圧レベルに ほとんど差はないので，それらを平均してダクト内平均 音圧レベル $\left(L p_{D}\right)$ とし, 式 $(12)$ より $L w_{D}$ を求め, ダクト内進行方向のパワーレベルとする。ここでの $L p_{D}$ は, 単なるダクト内の音圧レベルであって進行方 向の音圧レベルとは言いがたいが, 今回の実験では進行

\begin{tabular}{c|c} 
表-1 直管部の摩擦抵抗係数 $\bar{\lambda}$ \\
\hline $\begin{array}{c}\text { Type A (mmథ) or } \\
\text { Type B (mm) }\end{array}$ & $\begin{array}{l}\text { Friction } \\
\text { coefficient } \bar{\lambda}\end{array}$ \\
\hline 100 & 0.0320 \\
\hline 200 & 0.0377 \\
\hline 300 & 0.0307 \\
\hline $200 \times 200$ & 0.023 \\
\hline $200 \times 400$ & 0.020 \\
\hline $300 \times 300$ & 0.021 \\
\hline $300 \times 600$ & 0.022 \\
\hline $300 \times 1000$ & 0.022 \\
\hline $600 \times 600$ & 0.022 \\
\hline $600 \times 1000$ & 0.019 \\
\hline $1000 \times 1000$ & 0.019 \\
\hline
\end{tabular}

\begin{tabular}{c|c|c|c} 
表一2 & \multicolumn{2}{c}{ 円形断面曲管部の } \\
& \multicolumn{3}{c}{ 形状抵抗係数 $\bar{\zeta}$} \\
\hline \multirow{2}{*}{ Type } & \multicolumn{2}{|c}{ Duct Diameters d(mm) } \\
\cline { 2 - 4 } & 100 & 200 & 300 \\
\hline$C-1$ & 1.23 & 1.11 & 1.27 \\
\hline$C-2$ & 0.437 & 0.506 & 0.394 \\
\hline$C-3$ & 0.231 & 0.328 & 0.321 \\
\hline$C-4$ & 0.476 & 0.287 & 0.337 \\
\hline$C-5$ & 0.265 & 0.142 & 0.171 \\
\hline
\end{tabular}

表一3 正方形および長方形断面曲管部の形状抵抗係数 $\bar{\zeta}$

\begin{tabular}{|c|c|c|c|c|c|}
\hline & \multirow{2}{*}{ Type } & \multicolumn{4}{|c|}{ Duct Dimensions (mm) } \\
\hline & & $200 \times 200$ & $300 \times 300$ & $300 \times 1000$ & $600 \times 600$ \\
\hline & D-1 & 1.4 & 1.4 & 1.4 & 1.2 \\
\hline & $\mathrm{D}-2$ & 0.81 & 0.75 & 0.92 & 0.95 \\
\hline \multirow{3}{*}{$D-3$} & $\begin{array}{l}\text { Glass Wool } \\
\text { Turning Vanes }\end{array}$ & 0.59 & 0.39 & - & 0.38 \\
\hline & $\begin{array}{l}\text { Aruminium } \\
\text { Turning Vanes L }\end{array}$ & 0.65 & 0.61 & - & 0.45 \\
\hline & $\begin{array}{l}\text { Aruminium } \\
\text { Turning Vanes } \mathrm{S}\end{array}$ & 0.72 & 0.63 & - & 0.67 \\
\hline & $D-4$ & 0.60 & 0.49 & 0.90 & 0.67 \\
\hline & D-5 & -. & 0.38 & - & 0.33 \\
\hline
\end{tabular}

波成分を取り出すのが不可能であったため， $L p_{D}$ をダ クト軸進行方向の音圧レベルとし，また，3-2 同様ダク 卜内は，すべて平面進行波と仮定した。

図一 10 に示す供試ダクトの長さ 3.3 と $6.9 \mathrm{~m}$ の $L p_{o}$ と $L p_{D}$ との音圧レベル差はほぼ一定で, パワーレベル 差は供試ダクトの長さが 3.3 から $6.9 \mathrm{~m}$ に約倍になっ たぶんだけ後者の方がほぼ $3 \mathrm{~dB}$ 全体的に大きい。そこ で, ダクト外から内への遮音特性は, 単位長さ $(1 \mathrm{~m})$ 当たりのダクト侧壁への入射パワーレベル $\left(L w_{1}\right)$ とダ クト内パワーレベル $\left(L w_{D}\right)$ との差として表すことにす る(式 13)。ただし，ここでの遮音特性は, グラス・ファ イバ・ダクト側壁そのものの遮音量ではなく,ダクト内 の軸方向に進行する音に対しての外部からの音の影響を 考えての遮音特性である。

$$
\begin{aligned}
& L w_{I}=L p_{0}+10 \log _{10} A \\
& L w_{D}=L p_{D}+10 \log _{10} S
\end{aligned}
$$

Difference of $L w=L w_{1}-L w_{D}$

$L p_{0}$ : 残響室内平均音圧レベル $[\mathrm{dB}]$

$A:$ ダクト表面積 $\left[\mathrm{m}^{2}\right]$

$L p_{D}:$ ダクト内平均音圧レベル $[\mathrm{dB}]$

$S:$ ダクト断面積 $\left[\mathrm{m}^{2}\right]$

\section{4. 実験結果および考察}

\section{4-1：損失圧力}

直管部の摩擦抵抗係数 す。 $\bar{\lambda}$ は実験範囲内のレイノルズ数 $\left(0.3 \times 10^{5} \sim 5.0 \times 10^{5}\right)$ に対してほぼ一定値を示す。円形断面ダクトは，200Ф が 0.0377 以外は, ほぼ 0.031 前後, また, 長方形断面 ダクトは 0.021 前後を示し前者の方が後者に比べて大き い。

曲管部の形状抵抗係数 $\bar{\zeta}$ を表一 2 および表一 3 に示 す。円形断面ダクトでは, 2 ピースから 4 ピースにいく に従って, また, 角度が小さくなるに従って衣は小さ くなる。

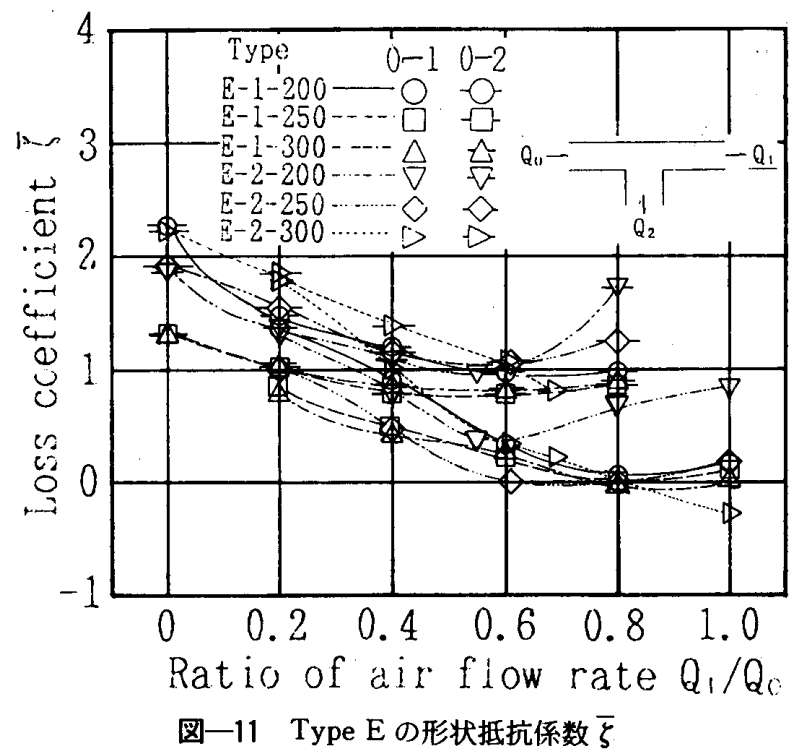


長方形断面ダクトも，ピース数が大きく，角度が小さ くなるほど守は小さくなり, $90^{\circ} \cdot 2$ ピースでは, Type D-2 は D-1 のそれより小さい。

また，ガイドベーン付きでは，それを付けない場合よ りも $\bar{\zeta} は 2 / 3$ 以下になる。ガイドベーシがグラスウー ル製とアルミニウム製のものとを比較すると前者の方が そは小さい。また，同じアルミニウム製でもベーンの数 が少なく長さが長い $L$ の方が $\overline{\zeta ~ か ゙ 小 さ い 。 ~}$

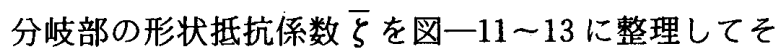
れぞれ示す。円形断面ダクト Type E は分岐分流抵抗係 数（区別するために分流側を分岐分流抵抗係数，直通側 を分岐直通抵抗係数とする）がほほ1.0 2.0 前後で, 分岐直通抵抗係数はそれより小さく 0.0 前後 1.5 以下 となり，直通側断面が $150 \Phi$ と他より小さい Type E-2 $200 \Phi$ では流量比 $Q_{1} / Q_{0}$ が 0.8 および 1.0 のときに分 岐分流および分岐直通抵抗係数いずれにおいても他より 大きい。正方形および長方形断面ダクト Type F-1 3 は分岐分流抵抗係数は 1.0 前後 2.0 以下で, 分岐直通 抵抗係数は, Type F-3 以外 0.0 前後となっている。

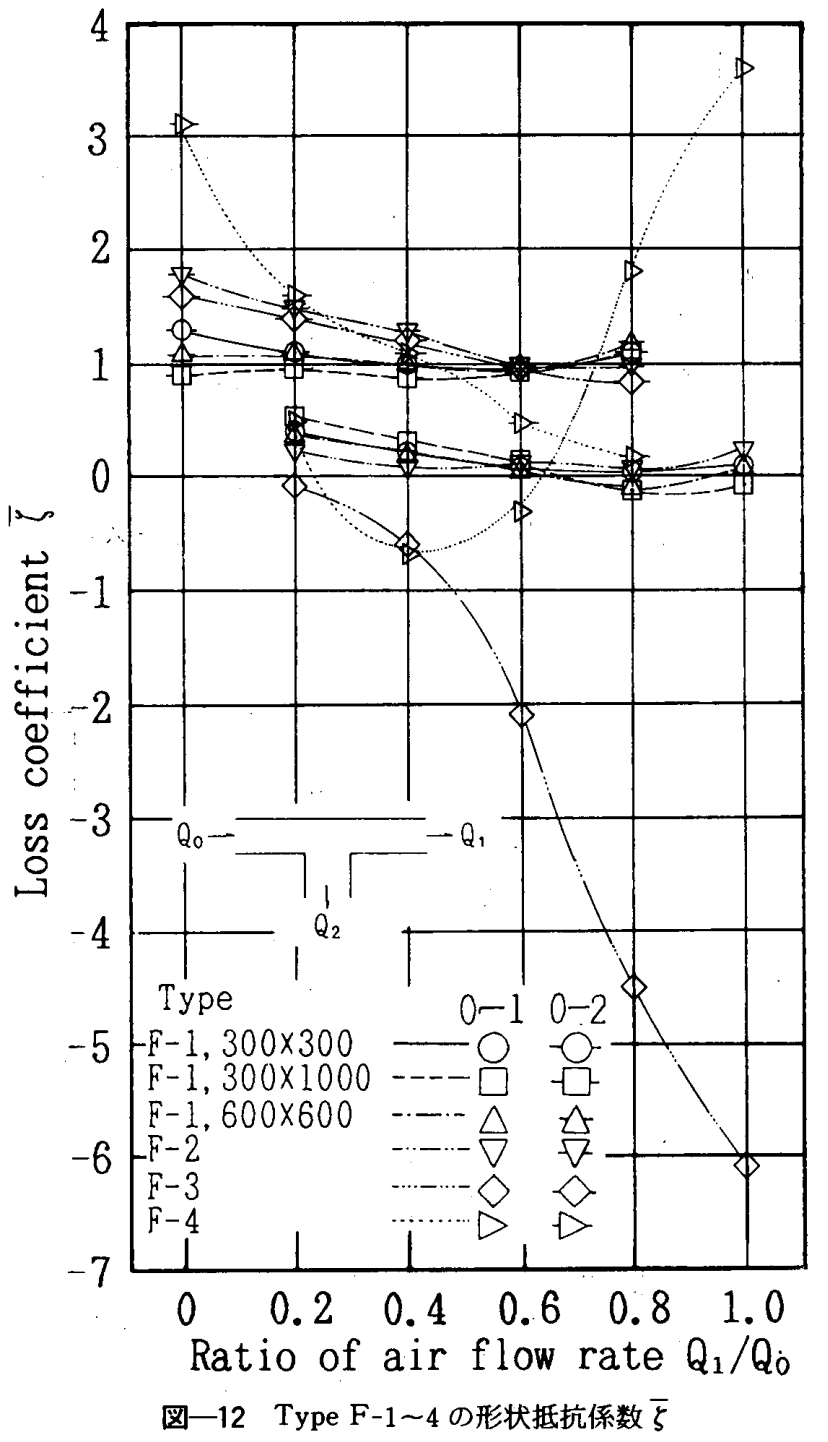

Type F-3 は，直通側が，“上流側や分流側に比してダク 卜断面が小さいため, すべてそれらは 0.0 以下となり流 量比 $Q_{1} / Q_{0}$ が 1.0 では -6.1 となっている。

また, 分岐部にガイドベーンを有する Type F-4では, 流量比 $Q_{1} / Q_{0}$ が大きくなれば, 分岐分流抵抗係数はほ ぼ3.1 0.0の間で次第に小さくなり, 分岐直通抵抗係 数は, 流量比 $Q_{1} / Q_{0}$ が, 0.4 のときに, 最小值を示し, それより大きくあるいは小さいと分岐直通抵抗係数は大

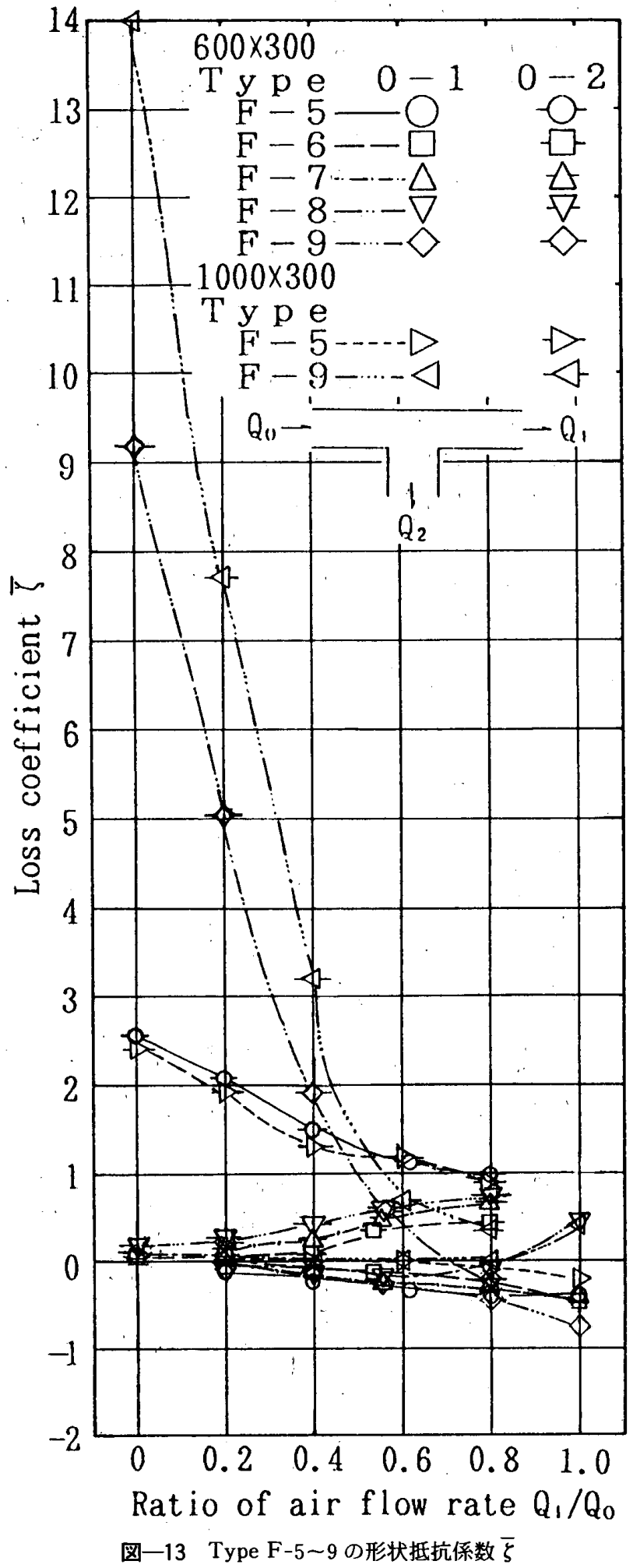


きくなり，流量比 $Q_{1} / Q_{0}$ が 1.0 で 3.6 となっている。

Type F-5 およびF-9 の抵抗係数は, $600 \times 300$ お び $1000 \times 300$ いずれも一部を除きほぼ同様な傾向を示 している。分岐直通抵抗係数は, Type F-5 9いずれ も 0.0 前後で \pm 1.0 以内におさまっている。分岐分流抵 抗係数は, Type F-5 は流量比 $Q_{1} / Q_{0}$ が大きくなると 2.5 1.0 前後の間で次第に小さくなり，分岐分流側の 入口が特殊な Type F-6〜8 は，Type F-5 と比べて分 岐分流抵抗係数は小さくなり, 流量比 $Q_{1} / Q_{0}$ が大きく なると0.0〜1.0の間で次第に大きくなる。Type F-9 では, 流量比 $Q_{1} / Q_{0}$ が小さくなるほど分岐分流抵抗係 数は大きくなり, 流量比 $Q_{1} / Q_{0}$ が, 0.0 で $600 \times 300$ が $9.1,1000 \times 300$ が 14 を示す。

\section{4-2：音響诚衰}

直管部の単位長さ $(1 \mathrm{~m})$ 当たりの音響减衰を図一14 〜16に示す。図一14 からグラスヤーンの有無は音響減 衰にはほとんど影響しない。

全体的にみて, 円形断面の直径あるいは正方形断面の 一辺が $200 \mathrm{~mm}$ のもの以外は, $1 \mathrm{kHz}$ 帯域に減衰量の最 大值がある。円形, 正方形および長方形断面いずれも有 効直径が大きくなるに従って減衰量は小さくなり, 有効 直径最大のダクト断面 $1000 \times 1000$ では，全周波数帯域 ほぼ一様な減衰量で, $3.5 \mathrm{~dB}$ 以下となる。円形断面の 直径あるいは正方形断面の一辺が $200 \mathrm{~mm}$ のものは, 2

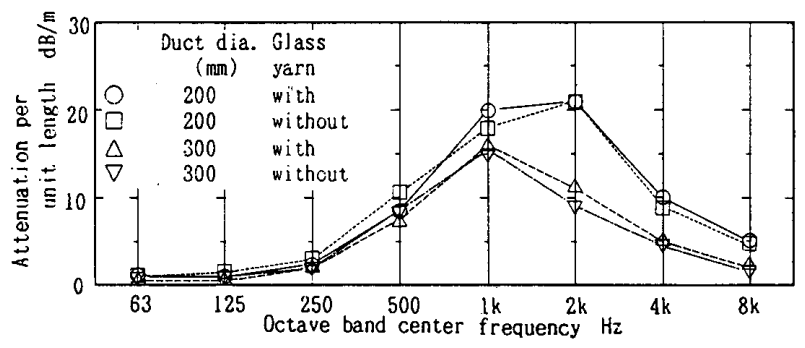

图一14 円形断面直管部の音響減衰

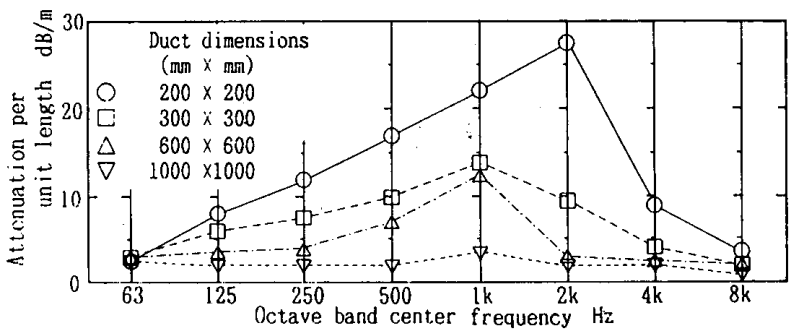

図一15 正方形断面直管部の音響減衰

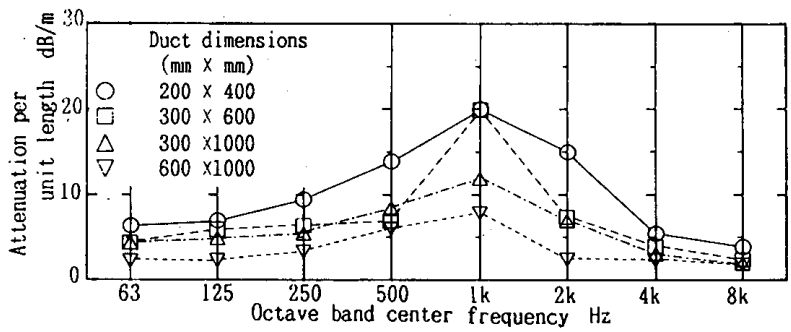

图一16 長方形断面直管部の音響减衰
$\mathrm{kHz}$ 帯域に最大值があり，特に，ダクト断面 $200 \times 200$ では, $30 \mathrm{~dB} / \mathrm{m}$ 近くまで達し，いずれも他の供試体に 比べて全体的に高い値を示している。

また，鉄板ダクト直後 $1 \mathrm{~m}$ までのグラス・ファイバ・ ダクトの音響减衰を図一17 -19に示す。

上記のグラス・ファイバ・ダクトそのものの音響減衰 量より全体的に大きいが，傾向としては，上記と同様， 円形，正方形および長方形断面いずれも有効直径が大き くなるに従って減衰量は小さくなる。また，円形断面の 直径あるいは正方形断面の一辺が $200 \mathrm{~mm}$ のものは, 2 $\mathrm{kHz}$ 帯域に最大值があり, いずれも他の供試体に比べ て全体的に高い值を示している。

鉄板ダクトの後にグラス・ファイバ・ダクト長さ $L$

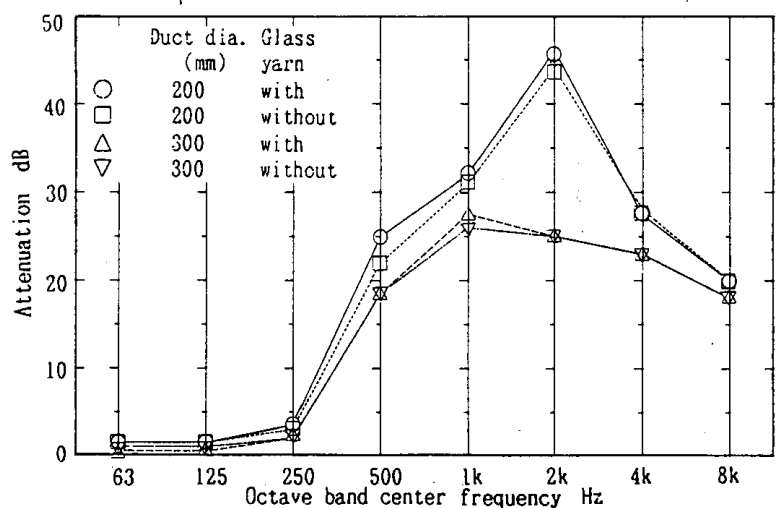

図一17 円形断面直管部の鉄板ダクト境界部から $1 \mathrm{~m} の$ 音響减 衰

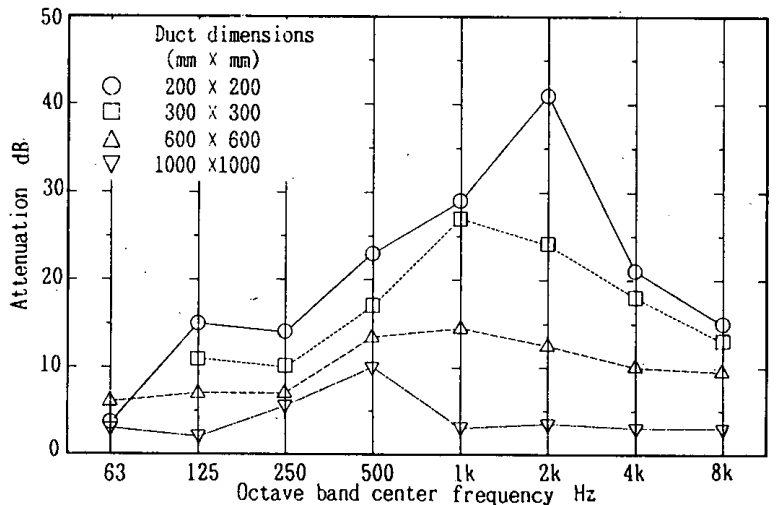

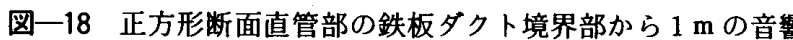
減衰

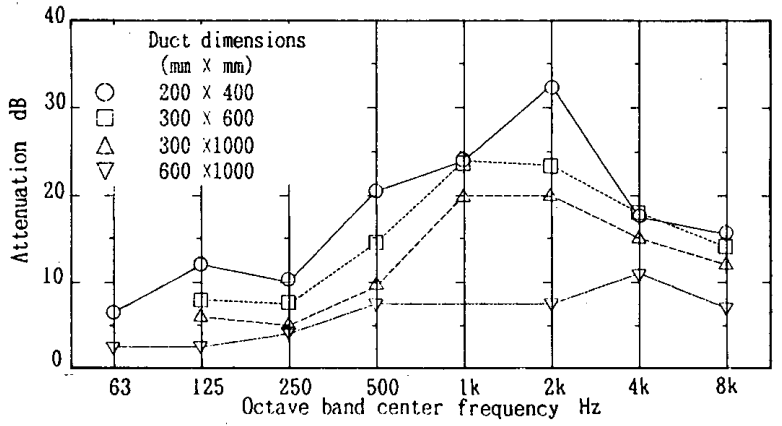

図一19長方形断面直管部の鉄板ダクト境界部から $1 \mathrm{~m} の$ 音期 減衰 
$\mathrm{m}$ を接続する場合のダクト内音響诚衰量は，図一17 19 のデータに図一14 16 のデー夕を(L-1) 倍した值 を加えることにより求めることができる。ただし，ダク 卜断面 $300 \times 1000$ の $2 \mathrm{k} ， 4 \mathrm{k}$ および $8 \mathrm{kHz}$ 帯域, 600 $\times 1000$ および $1000 \times 1000$ の $500 \mathrm{~Hz}$ 帯域においては, ダクトの長さ $L$ が $2 \mathrm{~m}$ 以上に限り，上記の方法で音響 減衰量を求めることができる。

曲管部の音響减衰を図一20 26に示す。図一20 22 を見ると円形断面曲管部 $100 \Phi, 200 \Phi$ および $300 \Phi$ の いずれにおいても 2 ピースは，曲がり角度 $90^{\circ}$ が全周波 数帯域において減衰量が大きく $45^{\circ}, 30^{\circ}$ の順に小さくな

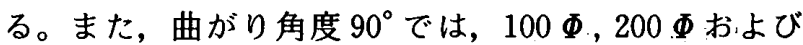
$300 \Phi$ は，いずれにおいても，2 ピースが他に比して大 きく，3ピースおよび 4 ピースは，ほぼ同様な傾向を示

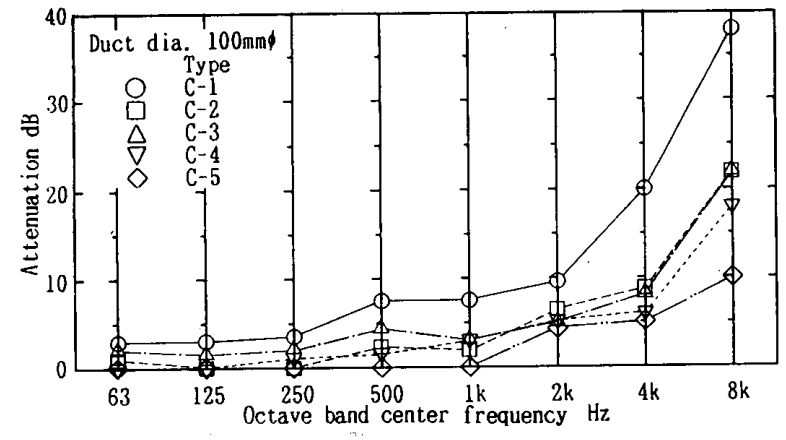

图一20 円形断面曲管部の音響娍衰

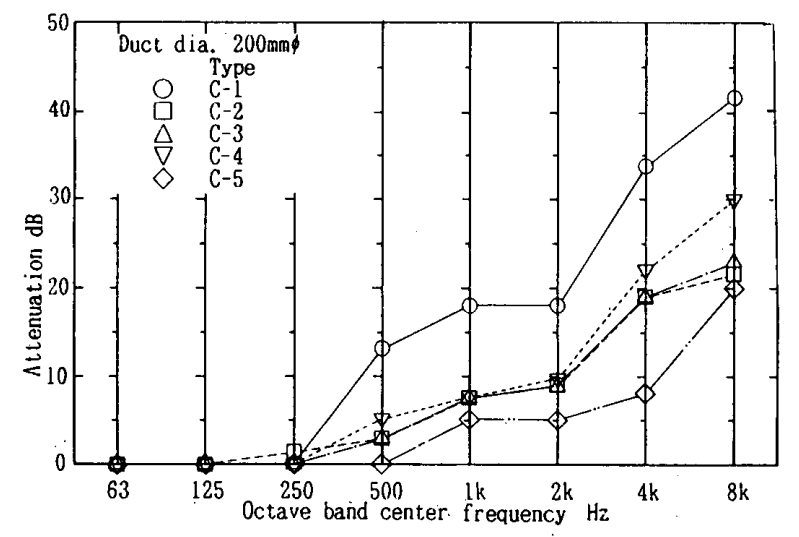

図一21 円形断面曲管部の音響减衰

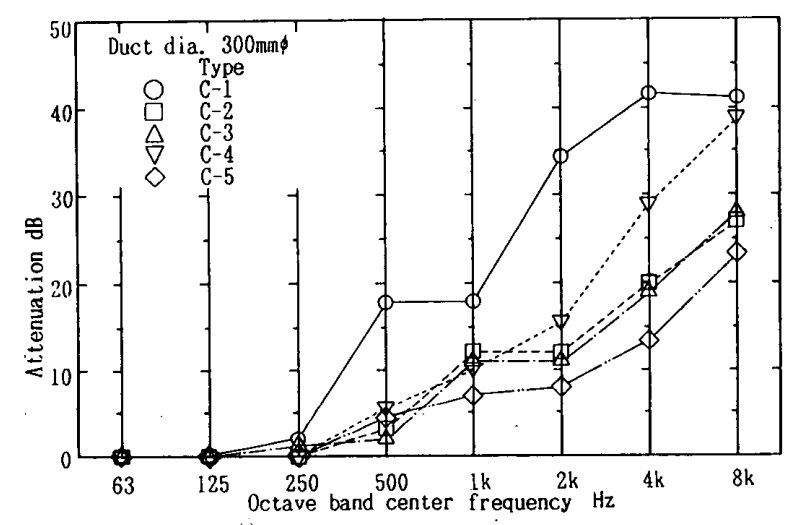

図一22 円形断面曲管部の音響减衰
している。

図一23〜25によれば，正方形断面曲管部 $200 \times 200$ で

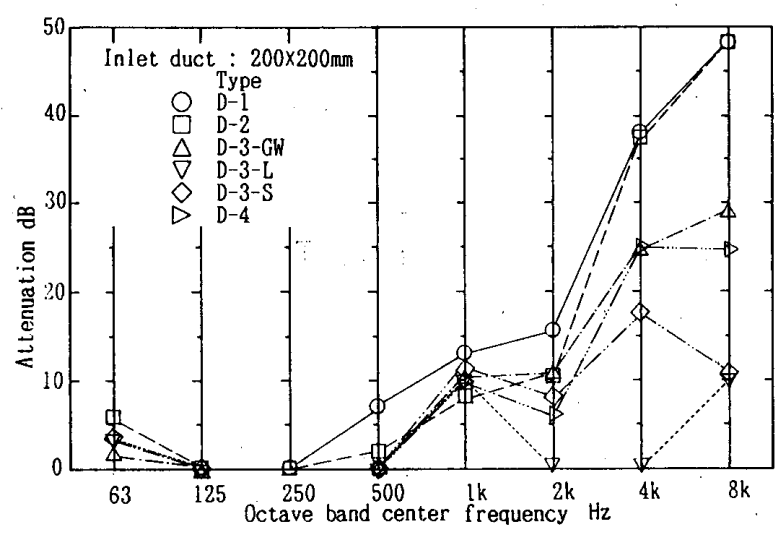

图一23 正方形断面曲管部の音響减衰

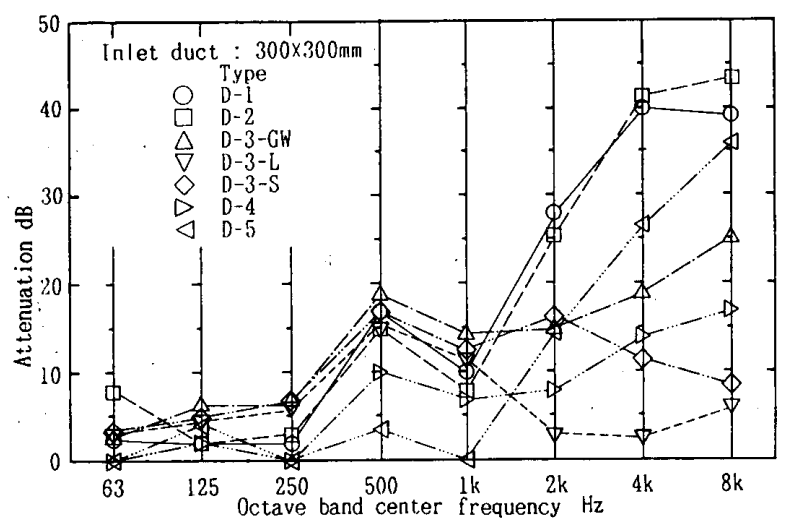

図一24 正方形断面曲管部の音響減衰

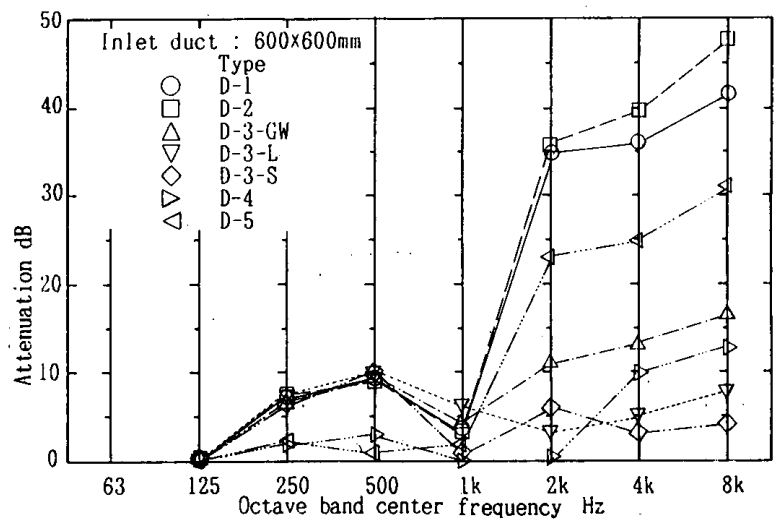

图一25 正方形断面曲管部の音響減衰

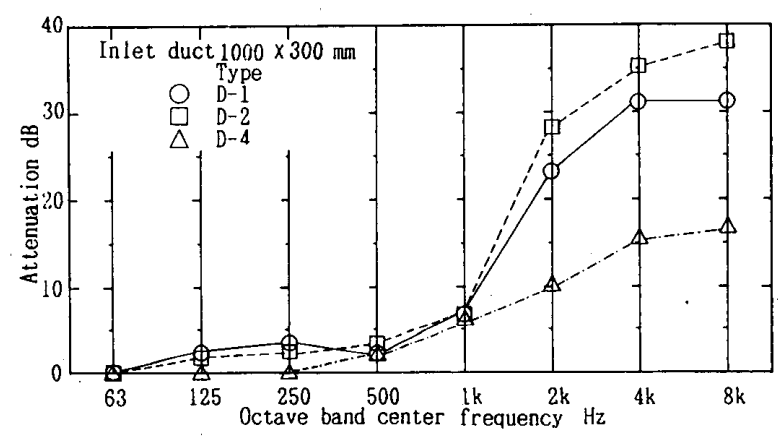

图一26 長方形断面曲管部の音響减衰 


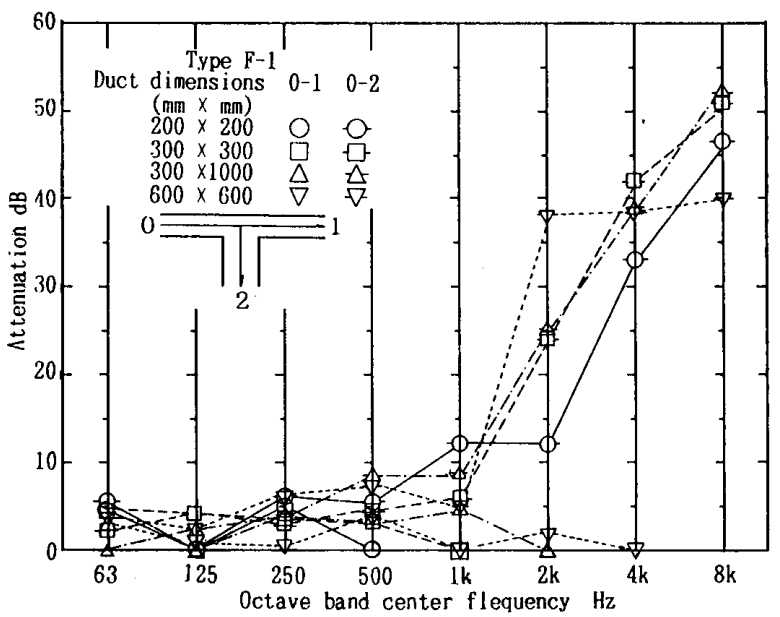

图一27正方形および長方形断面分岐部の音響减衰

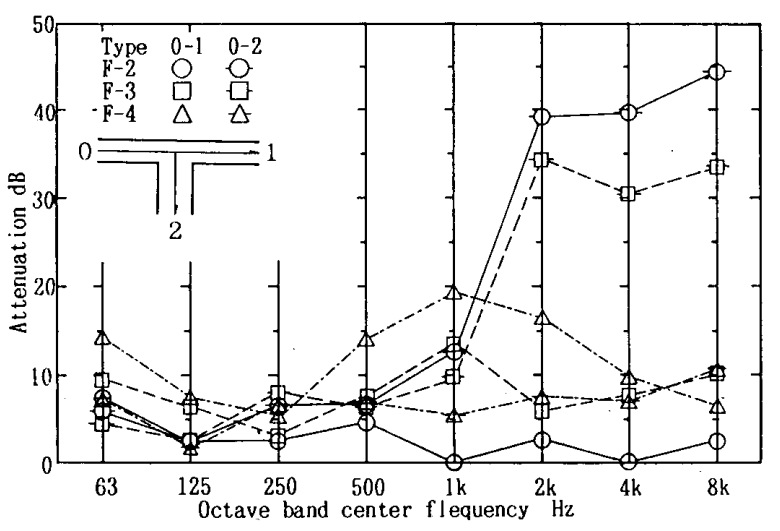

图一28 正方形および長方形断面分岐部の音㗽減衰

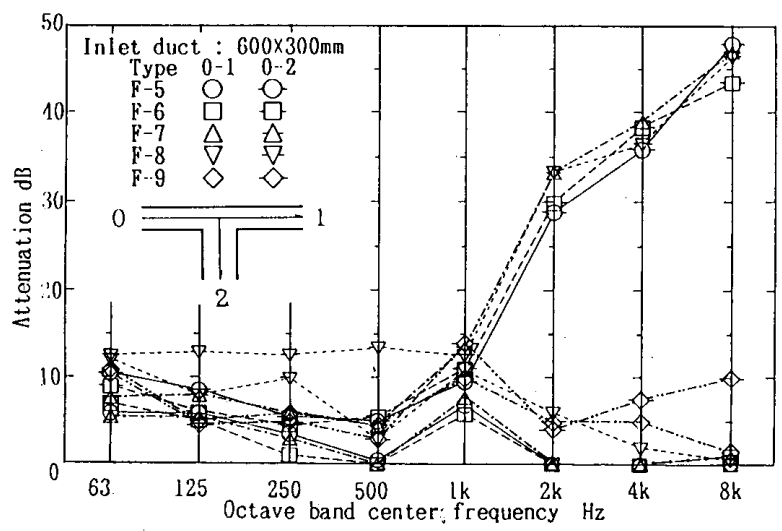

図一29正方形および長方形断面分岐部の音響减衰

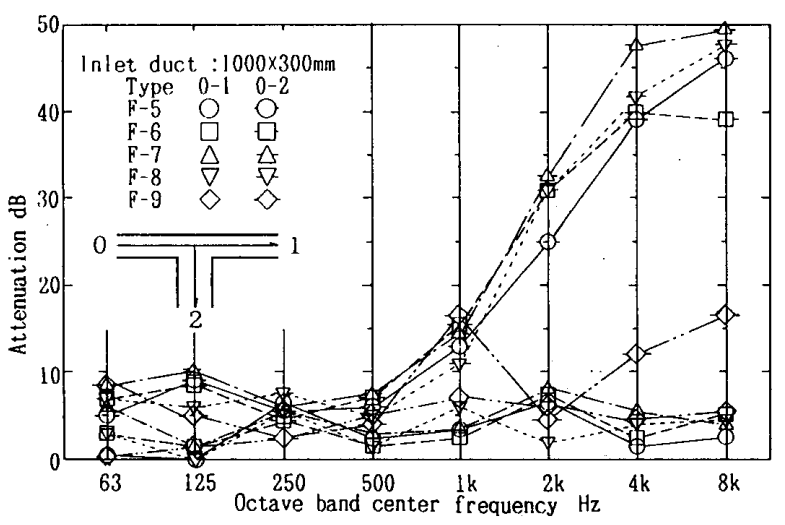

図一30 正方形および長方形断面分岐部の音響減衰
は $500 \mathrm{~Hz}$ および $2 \mathrm{kHz}$ 帯域で Type D-1 の方が, 300X 300 と $600 \times 600$ では高音域で Type D-2 の方が減衰量 は多少大きくなるが, 全体的にみて，ほぼ同様な傾向を 示している。それに比較して曲がり角度 $90^{\circ} \cdot 3$ ピースに なると 2 ピースに比べて $1 \mathrm{kHz}$ 帯域以上の周波数帯域 では減衰量に大きな差が生じる。

ガイドベーン付きでは， $1 \mathrm{kHz}$ 帯域以下は，3者いず れもほぼ同じような傾向を示すが，2-8 kHz 帯域にな るといずれもグラスウール製ガイドベーンが一番大き い。また， $200 \times 200$ および $300 \times 300$ では，アルミニウ 么製ガイドベーンの数が多い方が減衰量は大きく，600 $\times 600$ では，数による差はあまりみられない。

図一26によれば，長方形断面曲管部 $1000 \times 300$ は， Type D-1, 2 および 4 とも $1 \mathrm{kHz}$ 帯域以下では同様な周 波数特性を示しており, $2 \mathrm{kHz}$ 帯域以上では, D-2, 1 , 4 の順に大きく D-2 と D-1 では $5 \mathrm{~dB}$ 前後, D-1 と D-4 で 11 12 dB 前後の差がある。

分岐部の音響減衰を図一27 30に示す。

上流側ダクト, 下流側直通および分流ダクトの断面寸 法が等しい正方形および長方形断面分岐部 (Type F-1) は，直通側ではすべて $5 \mathrm{~dB}$ 以下である。また，分流側 では, $200 \times 200$ が $500 \mathrm{~Hz}$ 帯域以下では $6 \mathrm{~dB}$ 以下, 1 および $2 \mathrm{kHz}$ 帯域で $12 \mathrm{~dB}, 4$ および $8 \mathrm{kHz}$ 帯域で 33 および $46.5 \mathrm{~dB}$ となり， $4 \mathrm{kHz}$ 帯域から急激に減衰量が 大きくなる。 $300 \times 300$ は， $1 \mathrm{kHz}$ 帯域以下では, $6 \mathrm{~dB}$ 以下, $2 \sim 8 \mathrm{kHz}$ 帯域にいくに従って比例的に上昇して いく。また， $600 \times 600$ では，63，125 および $1 \mathrm{kHz}$ 帯域 が $5 \mathrm{~dB}$ 以下, 250 および $500 \mathrm{~Hz}$ 帯域が 6 および $7.5 \mathrm{~dB}$ となり, $2 \mathrm{kHz}$ 帯域で $38 \mathrm{~dB}$ と急激に上昇して, $2 \sim 8$ $\mathrm{kHz}$ 帯域では，ほぼ $39 \mathrm{~dB}$ 前後のフラットな值を示す。 また，長方形断面分岐部 $300 \times 1000$ では, $250 \mathrm{~Hz}$ 帯域 以下では $5 \mathrm{~dB}$ 以下, 500 および $1 \mathrm{kHz}$ 帯域で $8.5 \mathrm{~dB}$, そして $1 \mathrm{kHz}$ 帯域加ら上記の $300 \times 300$ と同様に比例的 に上昇していく。上流側ダクト断面が $600 \times 600$ で分岐 管断面がそれより小さい分岐部をまとめた図一 28 によ れば，分流ダクト断面 $450 \times 450$ で，直通ダクト断面が $450 \times 450$ (Type F-2) と $250 \times 250$ (Type F-3) の分 流側では, $1 \mathrm{kHz}$ 帯域以下は，ほぼ同様な周波数特性 を示しており， 2 および $4 \mathrm{kHz}$ 帯域に $10 \mathrm{~dB}$ 以上の差が 表るが, 図一 27 の $600 \times 600$ と同様に $2 \sim 8 \mathrm{kHz}$ 帯域は フラットになる傾向がある。また，直通側では，全周波 数帯域において後者の方が大きい。

ベーンがあるものは, 分流側が $7 \mathrm{~dB}$ 前後のフラット な周波数特性となり，直通側は， $500,1 \mathrm{k}$ および $2 \mathrm{kHz}$ 帯域がベーンなしより 7 10 dB 大きくなる。

また, 分岐分流ダクトの入口の差異による特性を示し た図一 29 および 30 によれば, $600 \times 300$ では Type F-8 と 9 以外はほとんど同様な特性を示す。Type F-8 およ 
び 9 では，直通側が他の 3 者に比べて全体的に大きめで ある。また, 分流側では, F-8 は, $1 \mathrm{kHz}$ 帯域までほほ $13 \mathrm{~dB}$ 前後のフラットな特性となり, $1 \mathrm{kHz}$ 帯域以上で は，前の 3 者と同様な特性を示す。また，F-9 のガイ ドベーン付きでは， $1 \mathrm{kHz}$ 帯域以下では，F-5〜7 と同 様な特性を示すが, $2 \sim 8 \mathrm{kHz}$ 帯域では $4,8,10 \mathrm{~dB}$ と他 と比べて $30 \mathrm{~dB}$ 以上小さい。

また，それよりも断面が大きい $1000 \times 300$ では，600 $\times 300$ とほぼ同様な傾向を示すがより詳細に検討すれ ば;; Type F-5 8 の直通側は, 250 と $2 \mathrm{kHz}$ 帯域に 7 $\mathrm{dB}$ 前後の山を持つほぼ類似の特性を示し，ガイドベー ン付きは， $1 \mathrm{kHz}$ 帯域に $7 \mathrm{~dB}$ のピークを持つなだらか な特性になる。また，分流側では，F-9 以外は，いず れも同様な傾向を示すが， $600 \times 300$ と異なり $2 \mathrm{kHz}$ 帯 域以上に 7 10 dB の差がみられる。また, ガイドベー ン付きは, $2 \mathrm{kHz}$ 帯域以上で他に比較して $30 \mathrm{~dB}$ 前後 の差がある。

\section{4-3：側壁の遮音特性}

直管部のダクト内から外へ透過する場合の単位長さ (1 m) 当たりの供試体入口のパワーレベルとダクト側

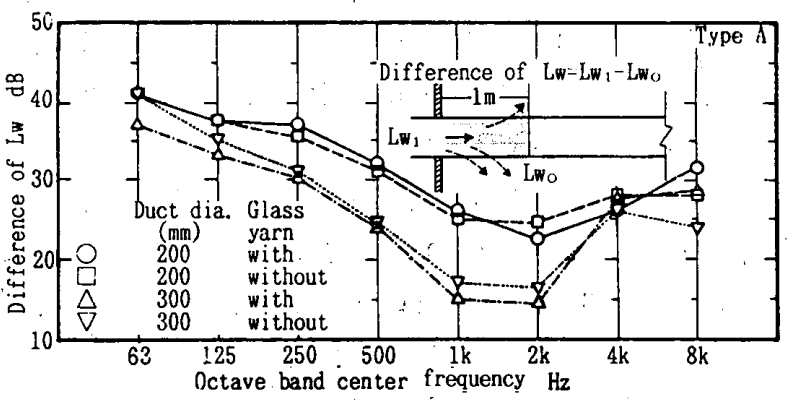

图一31 ダクト内から外へ透過する場合の遮音特性

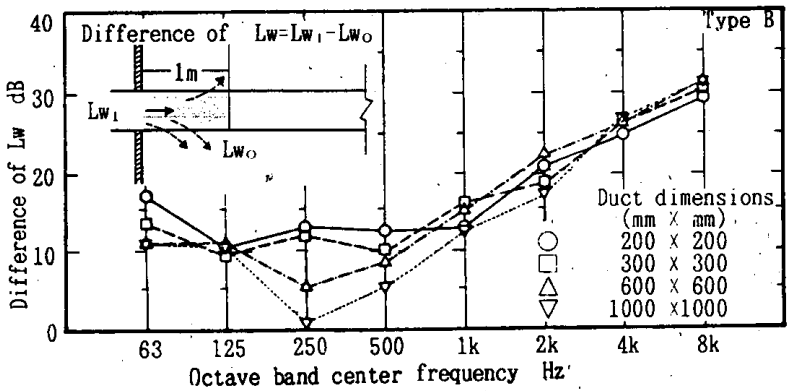

図一32 ダクト内から外へ透過する場合の遮音特性

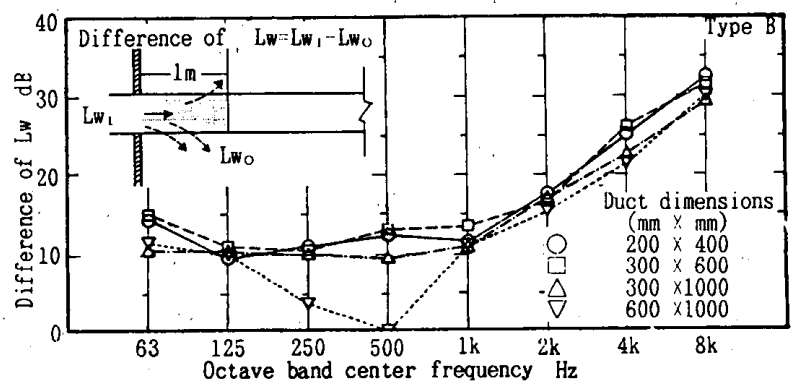

图一33 多㐻ら外へ透過する場合の遮音特性
壁からの透過パワーレベルとの差を図一31〜33に示す。 円形断面ダクトでは, $1 \mathrm{kHz}$ 帯域付近まで周波数が高く なるにつれてパワーレベル差が減少する。グラス・ヤー ンの有無による差は少ない。正方形および長方形断面ダ クトでは, $1 \mathrm{kHz}$ 帯域以上でパワーレベル差がダクト断 面によらずほぼ等しく，周波数が高くなるにつれて増大 する。

直管部のダクト外から内へ透過する場合の単位長さ (1 m) 当たりの供試ダクト側壁への入射パワーレベル とダクト内パワーレベルとの差を図一34〜36に示す。 円形断面ダクトのパワーレベル差は，ほぼ一様な周波数 特性を示し，全体的にみてグラス・ヤーンが有るときよ りも無い方が遮音性能が良い。正方形および長方形断面 ダクトでは，一部を除き周波数が高くなるにつれてパ ワーレベル差も增大する。

遮音性能は，円形断面ダクトの方が正方形および長方 形断面ダクトよりダクト内から外およびダクト外から内

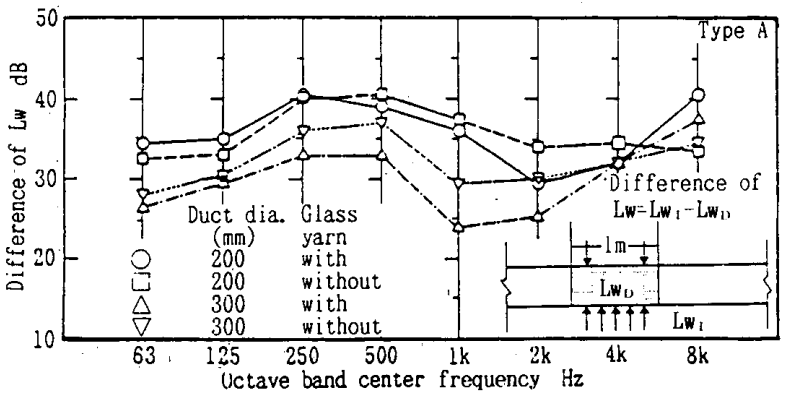

図一34 ダクト外から内へ透過する場合の遮音特性

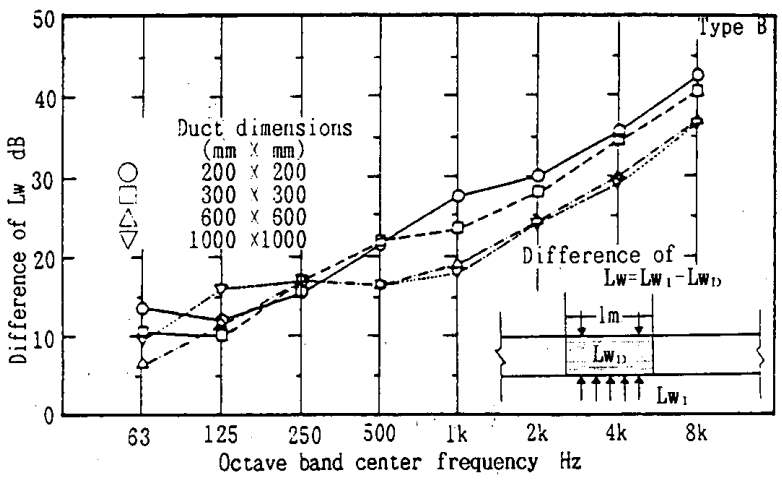

图一35 ダクト外から内へ透過する場合の遮音特性

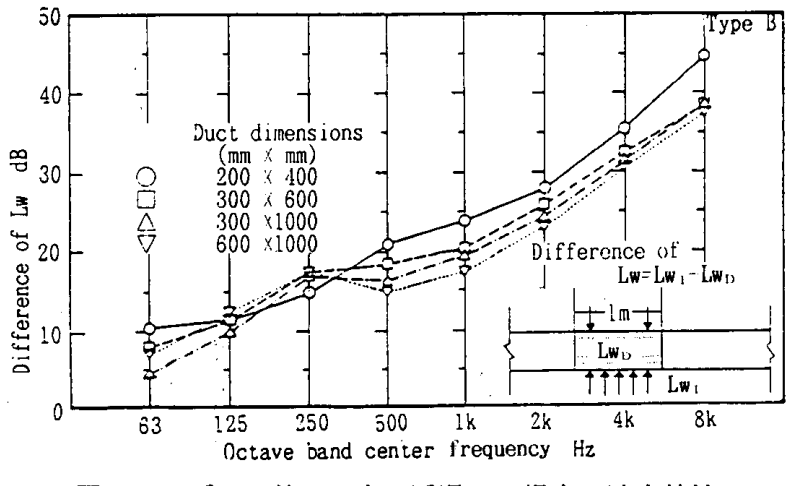

图一36 ダクト外から内へ透過する場合の遮音特性 
へ透過する場合いずれにおいても良い性能を示す。

\section{5. 結 論}

今回実験を行った供試体の特徵を以下にまとめる。 $5-1 ：$ 直管部

a) 円形断面ダクトの摩擦抵抗係数 び長方形断面ダクトのそれょり大きい。円形断面 $200 \Phi$ のダクトは, 他の円形断面ダクトと比べて 1.2 倍前後大 きい。

b）鉄板ダクトとグラス・ファイバ・ダクトとを併用 して用いる場合, 鉄板ダクト直後 $1 \mathrm{~m}$ とそれ以降とで は減衰量が異なる。

c）音響減衰は，円形断面 $200 \Phi$ およ゙正方形断面 $200 \times 200$ のものが他と比べて $2 \mathrm{kHz}$ 帯域に異常に大き な減衰量をもち, その他は, $1 \mathrm{kHz}$ 帯域に減衰量の最 大值があり，いずれも有効直径が大きくなるに従ってそ れらは小さくなる。

d）遮音性能は, 円形断面ダクトの方が正方形および 長方形断面ダクトよりダクト内から外およびダクト外か ら内へ透過する場合いずれにおいても良い性能を示す。 また，グラス・ヤーンの有無は，音響減衰およびダクト 内から外へ透過する場合の遮音性能にはあまり差はな く，ダクト外から内へ透過する場合の遮音性能で有ると きより無い方が良い性能を示す。

$5-2 ：$ 曲管部

a) 形状抵抗係数 た，角度が小さくなるに従って小さくなる。

b）音響減衰は，角度が小さくなると減衰量も小さく なり，円形断面ダクトでは，2ピースがもっとも大きく， 3 ピースと 4 ピースは同様な傾向を示しており，正方形 および長方形断面ダクトにおいても，2 ピースより 3 ピースの方がそれは小さい。

c）ガイドベーン付きは，付けないものよりも形状抵 抗係数 $\bar{\zeta}$ は $2 / 3$ 以下となり, $1 \mathrm{kHz}$ 帯域以下では音響減 衰量は両者ともあまり差はなく，それよりも高い周波数 帯域で大きな差が生じ前者は後者のほぼ $1 / 2$ になる。グ ラスウール製ガイドベーンがアルミニウム製のそれより ラは小さく音響减衰量は大きい。また, ベーンの数が少 なく長さが長い方が全体的にそれらは小さい。

$5-3:$ 分岐部

a) 分岐直通側と分流側とでは，いずれの流量比にお いても全体的に後者の方が形状抵抗係数高は大きい。

b）分岐直通側では断面寸法や流量によって 0 以下に なるものがある。 c）ガイドベーン付きでは,ガイドベーンなしに比し， 流量比により抵抗係数が大きく変化する。

d）音響減衰は，直通側ではすべて $10 \mathrm{~dB}$ 以下であ り, 分流側も $500 \mathrm{~Hz}$ 帯域以下では直通側とほぼ同様な 傾向を示しており, $1 \mathrm{kHz}$ 帯域以上で急激に減衰量が大 きくなる。ガイドベーン付きでは，分流側の $1 \mathrm{kHz}$ 帯 域以上がほとんど直通側と近い値になり，逆にそれより 小さくなるものもある。また，分流側のダクト入口の違 いによる大きな差は見られない。

\section{謝 辞}

本研究にあたり当時 $\mathrm{k} . \mathrm{k}$. 東京興業貿易商会およびマ イクロ・ダクト・システム k. k. の加藤孝義氏, 日本板 硝子 k. k. の寺嶋健二氏に多大のご協力をいただいた。 また，本実験において，当時日大助手であった飯島和俊 氏（現日本ノイズ・コントロール k. k. ), 日本大学の大 学院生, 卒論生の諸君の労を多とした。ここに記して深 謝する。

\section{参考文献}

1）勝田高司，後藤 滋，寺沢達二：ファイバー・ダクトの 遮音性能に関する実験; 生産研究, Vol.11, No.4, pp. $27 \sim 28,1959.8$

2）長友宗重ほか：グラスウールダクトの诚音特性について； 日本建築学会論文報告集, 号外, pp. 564，1967

3）板本守正ほか 1 名：グラス・ウール・ダクト系の損失圧 力について; 日本建築学会大会学術講演梗概集, pp. 371 $\sim 372,1977.10$

4）板本守正ほか 4 名：セル型消音器の音響特性について; 日本建築学会大会学術講演梗概集, pp. 183 184, 1978. 9

5）板本守正ほか 4 名：グラス・ファイバ・ダクトの音響特 性について; 日本建築学会大会学術講演梗概集, pp. 185 $\sim 186,1978.9$

6）板本守正ほか 2 名：グラス・ファイバ・ダクト系の曲管 部, 分岐部および吹出しロユニットの音響特性について； 日本建築学会大会学術講演梗概集, pp. 105 106, 1980.9

7）板本守正ほか 1 名：グラス・ファイバ・ダクト系の損失 圧力について; 日本建築学会大会学術講演梗概集, pp. $485 \sim 486,1984.10$

8）板本守正：グラス・ファイバ・ダクトの音響特性につい $\tau$; 空気調和・冷凍連合講演会講演論文集, pp. 29 32, 1978. 4

9）板本守正：グラス・ファイバ・ダクト系の性能について; 空気調和・衛生工学会学術論文集, pp. 193 - 196, 1985. 10 


\section{SYNOPSIS}

UDC : 534. $831: 628.517: 696 / 697$

ON AIR FLOW AND SOUND CHARACTERISTICS OF STRAIGHT DUCTS, ELBOWS AND DIVIDED-FLOW FITTINGS OF GLASS FIBER DUCT SYSTEMS

by Dr. MORIMASA ITAMOTO, Professor of Nihon Univ. and HIROYOSHI SHIOKAWA, Assistant of Nihon Univ., Member of A. I. J.

For evaluating the air flow and sound characteristics of straight ducts, elbows and divided-flow fittings of glass fiber duct systems, the variations of ducts are studied.

Experimental methods to evaluate air flow and sound characteristics of glass fiber duct systems are described.

Pressure loss, sound attenuation and sound insulation characteristics of duct wall are discussed. 